\title{
Legume Genomics and Breeding
}

Rajeev K. Varshney and Mahendar Thudi

International Crops Research Institute for the Semi-Arid

Tropics (ICRISAT)

Patancheru, PO 502324, India

Greg D. May

National Center for Genome Resources

2935 Rodeo Park Drive East

Santa Fe, NM 87505

Scott A. Jackson

Department of Agronomy

Purdue University

West Lafayette, IN 47907

I. INTRODUCTION

II. CONSTRAINTS IN CROP PRODUCTION
A. Abiotic Stresses
1. Drought
2. Salinity
B. Biotic Stresses
1. Fungal Diseases
2. Viral Diseases
3. Insect Pests and Nematode Diseases

III. GENOMIC RESOURCES IN LEGUMMES
A. Genome Sequencing for Understanding Genome Architecture
B. Species-Specific Genomic Resources
1. Molecular Markers
2. Genetic Maps
3. BAC Libraries and Physical Maps
4. Transcriptome Resources

Plant Breeding Reviews, Volume 33 Edited by Jules Janick Copyright (c) 2010 Wiley-Blackwell. 


\section{TRAIT MAPPING AND MARKER-ASSISTED SELECTION \\ V. SUMMARY AND PROSPECTS \\ ACKNOWLEDGMENTS \\ LITERATURE CITED}

\section{INTRODUCTION}

Legumes account for $27 \%$ of the world's crop production, with grain legumes alone contributing $33 \%$ of the dietary protein nitrogen needs of humans (Vance et al. 2000). Grain and forage legumes are grown on some 190 million hectares, and their production is about 300 million metric tons across the world. Grain legumes are also a rich source of essential vitamins, minerals, and important amino acids (Duranti and Gius 1997; Grusak 2002). Moderate consumption of legumes helps to prevent cardiovascular diseases, stroke, Parkinson's disease, Alzheimer's disease, and even cancer (Singh 2007). Proteins of grain legumes are generally high in lysine but low in methionine and cysteine. However; combined with cereals, they result in a balanced diet of energy and protein. In fact, grain legumes are critical components in the diets of resource-poor people in the developing world, especially for vegetarian populations and those who cannot afford to supplement their diets with meat. Legume crops also garner higher market prices than other staple crops and are therefore attractive to farmers.

From an agronomic perspective, the ability of legumes to fix atmospheric nitrogen $(\mathrm{N})$ in the soil through their symbiotic association with Rhizobium bacteria (Schultze and Kondorosi 1998; Serraj 2004), thereby reducing the need for fertilizers, and to serve as rotation crops is very important to current-agricultural production systems. For instance, under nitrogen-limiting conditions, legume-Rhizobium symbiosis results in the formation of the root nodules. Rhizobium bacteria that harbors in the root nodules differentiate the nodules into symbiotic bacteroids that are the sites of catalysis of dinitrogen into ammonia by nitragenase. As an energy source to achieve $\mathrm{N}$ fixation, the bacteria obtain dicarboxylic acids from the host plant. By a complex amino acid cycle, the reduced $\mathrm{N}$ is provided to the plant (Lodwig and Poole 2003), where it is accumulated into proteins. Thus legumes can also help replenish nutrient-depleted soil.

The leguminosae (Fabaceae), contain over 18,000 species divided into the three subfamilies Mimosoideae, Caesalpinoideae, and Papilionoideae. The majority of species of Papilionoideae are herbaceous, although some are trees and shrubs. By contrast, majority of Caesalpinoideae are 
tropical and subtropical trees, while Mimosoideae include trees and shrubs. It is an extraordinarily diverse family of worldwide distribution with representatives occurring from alpines, to arctic regions, to equatorial tropics. Major dietary legumes include soybean (Glycine max, the single major contributing species, which is used for multiple applications in the food and feed industries); peanut (Arachis hypogaea); cowpea (Vigna unguiculata); common bean (Phaseolus vulgaris); chickpea (Cicer arietinum); pigeonpea (Cajanus cajan); lentil (Lens culinaris); mung bean (Vigna radiata); and faba bean (Vicia faba); all that contribute significantly to the diets of large numbers of people in Asia, Africa, and South America (Table 6.1). As the majority of these legume crops are grown in marginal environments of Africa and Asia, their production is heavily challenged by a number of abiotic (drought, freezing, salinity, waterlogging) and biotic (fungi, bacteria, nematodes, viruses, insects, parasitic plants) stresses.

The unique nature of legume species, due to their symbiotic interactions with specific soil-borne bacteria, the rhizobia, to fix atmospheric $\mathrm{N}$ attracted the plant science community to undertake large-scale investigations in legume species. As a result, two species, Medicago truncatula (Cook 1999) and Lotus japonicus (Handberg and Stougaard 1992), emerged as model legumes to understand the genetics and molecular biology of nodulation (Stacey et al. 2006) and other important processes, such as resistance or tolerance to stresses (Dita et al. 2006). Their small diploid genomes, autogamous nature, short generation times, and prolific seed production made them ideal choices for undertaking genomics research, including genome sequencing. As a result, powerful genetic and genomic tools, such as establishment of genetic and physical maps (Pedrosa et al. 2002; Thoquet et al. 2002), expressed sequence tags (ESTs) (Asamizu et al. 2004; Kulikova et al. 2001), genome-wide sequence data (Young et al. 2005; Cannon et al. 2006), bioinformatics tools and databases (Town 2006), functional genomics, and metabolomics platforms, have been developed for these two legume species (see Varshney et al. 2009). Furthermore, due to unique importance of soybean in North America and its emergence as a bioenergy crop, the soybean genome was also targeted by Joint Genomics Institute of Department of Energy (JGI-DoE) of the United States for genome sequencing.

Due to the phylogenetic relationships within the legume family (Mahalakshmi et al. 2002; Wojciechowski et al. 2004), heavy investments in Medicago, Lotus, and soybean research fueled expectations that this genomic and biological knowledge information could be transferred from reference legumes to other food and feed legumes of major economic importance. Recent years, however, have witnessed significant 


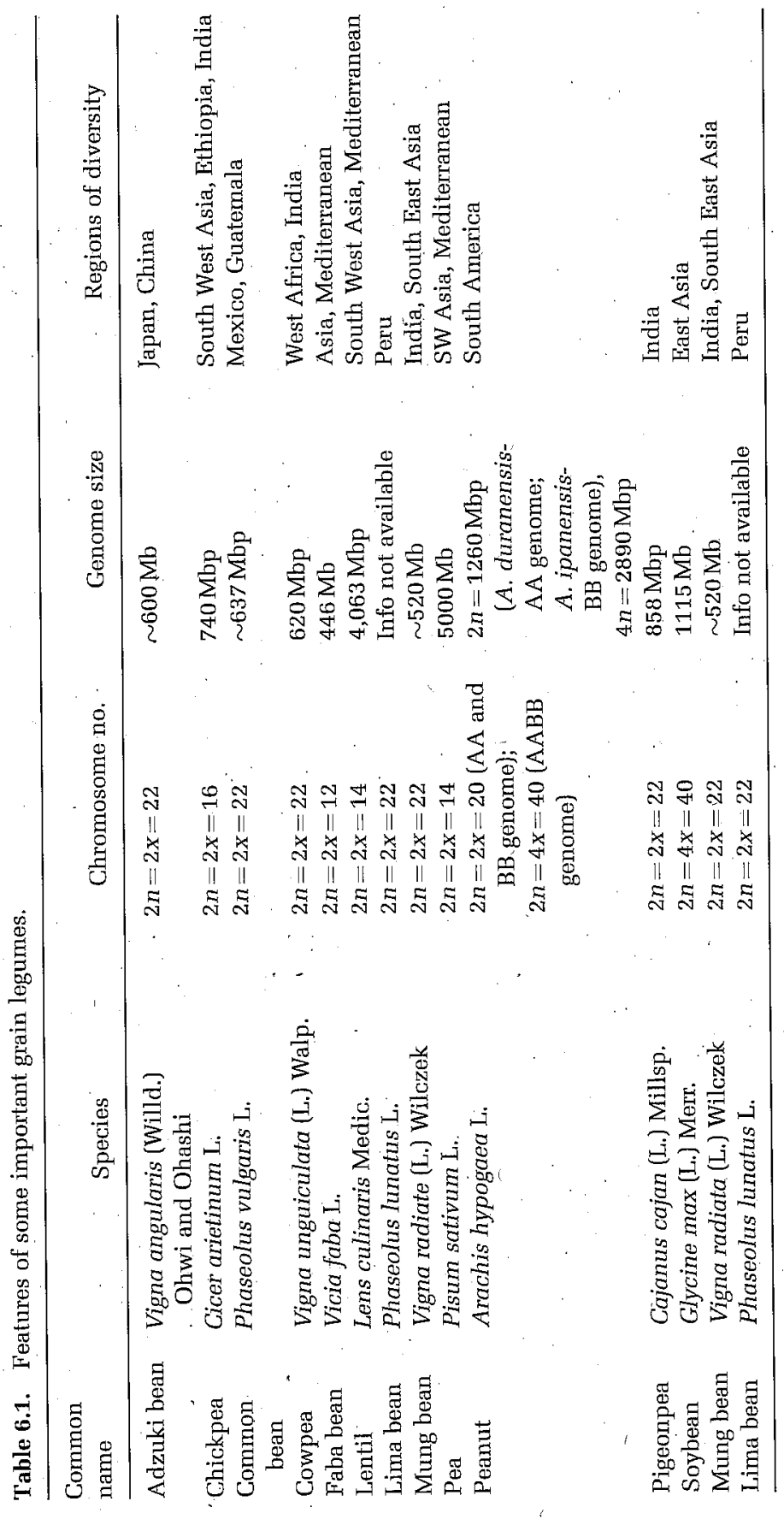


progress towards developing genome-specific genomic resources in these food legume crops as well. This chapter provides an update on recent progress in the area of legume genomics and their applications in legume breeding.

\section{CONSTRAINTS IN CROP PRODUCTION}

Legumes are the second most important crop plants after the Gramineae in their importance to humans. Unfortunately, improvements in legume crop yields have not kept pace with those of cereals (Fig. 6.1). Several abiotic (drought, freezing, salinity, waterlogging) and biotic (fungi, bacteria, nematodes, viruses, parasitic plants, insects) factors are major constraints to sustainable legume production, especially in the tropical and subtropical regions of the world. In addition, nutrient depletion of soils is a particular problem for small landholders in developing countries, where much grain-legume production occurs, and many farmers cannot afford to use fertilizers. Progressive soil chemical and physical degradation and acid soil conditions may also limit legume productivity.

\section{A. Abiotic Stresses}

Maintaining or improving crop productivity under conditions of abiotic constraints in the field is a major concern for farmers in many areas in the world where legumes are grown. The adaptability and productivity of legumes are limited by major abiotic stresses including drought, heat, frost, chilling, waterlogging, salinity, and mineral toxicities. Rainfed

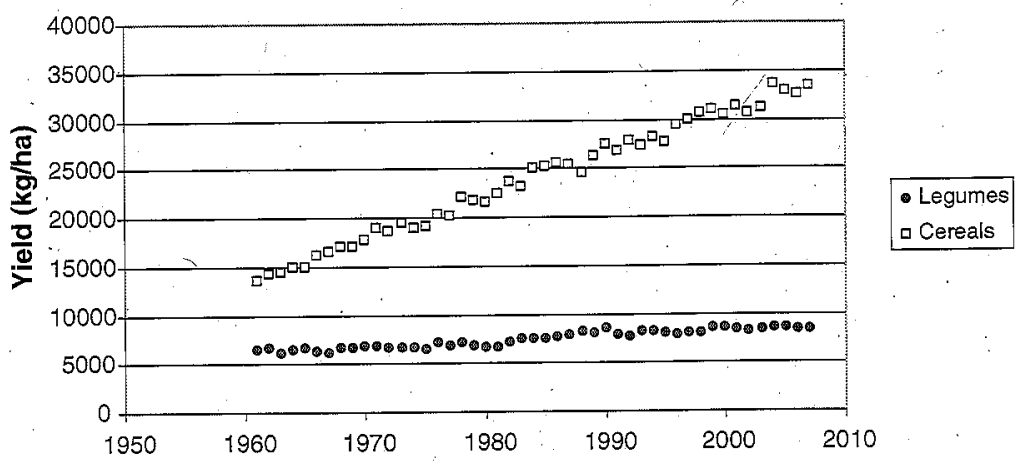

Fig: 6.1. Comparative trends in yield distribution of selected cereal and legume crops during last six decades. Comparison shows the continuous increase in total yield of cereals while stagnant or slow increase in the yield of legumes. 
legumes are often exposed to terminal drought due to inadequate rains to meet the water requirements during pod filling. Cultivation of legumes under irrigated conditions for prolonged periods or use of ground water for irrigation, however, invariably leads to higher sodicity or salinity in the agricultural production systems. In fact, drought and salinity are considered among the most severe stresses for legume-growing areas.

1. Drought. Drought is one of the most severe stresses for the sustainable legume production especially in the semiarid tropics (SAT) where short and erratic rainfall is common. SAT legume crops are grown under rainfed conditions and suffer from both intermittent and terminal drought stress, thus incurring major yield losses. Worldwide, yield losses each year due to drought are estimated to be around US\$500 million (Sharma and Lavanya 2002).

Water uptake and water-use efficiency of crop plants are two major factors that influence their yield. Hence, there is a greater need for a more comprehensive understanding of root biology in those crops where roots have already proved to be beneficial for yield under terminal drought (common bean, soybean, chickpea) and to explore these traits in those crops where there is little information on roots (e.g. peanut). Specifically, there is a need to understand the dynamics of roots, how roots contribute to the overall water budget, especially how they contribute at the time of grain filling. Recent studies at the International Crops Research Institute the Semi-Arid Tropics (ICRISAT, India) indicate that deeper rooting correlates with a higher harvest index (HI) in chickpea in conditions of more severe drought (Kashiwagi et al. 2005, 2006; Vadez et al. 2008). Transpiration efficiency (TE) is another trait that is being addressed in some legume crops such as peanut using different biotechnological, physiological, and breeding approaches (Krishnamurthy et al. 2007).

2. Salinity. Soil salinity is another important limiting factor for crop yield improvement; it affects $5 \%$ to $7 \%$ of arable lands (i.e., approximately 77 million ha worldwide) (Oldeman et al. 1991). Legumes, in general, are sensitive to salinity, and within legumes, chickpea, faba bean, and pigeonpea are more sensitive than other food legumes. The salinity problem is increasing, particularly in areas where irrigation is a common practice. Although management options exist to alleviate salt effects, these options often contradict the immediate economic choices of concerned farmers; thus, crop improvement for salt tolerance appears to be the only alternative.

The problem of salinity is basically two-fold. First, soil is saturated with sodium $(\mathrm{Na})$ and soil $\mathrm{pH}$ remains within an optimal range for crop 
growth. This type of salinity refers to coastal or dryland salinity. These are soils that get saturated with sodium because an existing saline ground water table is rising (proximity to the sea or salt that has accumulated in the soil profile), bringing the salt to the surface. Second, soil is both saturated with $\mathrm{Na}$ (exchangeable sodium percentage, ESP > 6) and $\mathrm{pH}$ has reached levels above 8.5. This type of salinity is also called transient salinity and is hereafter referred to as sodicity or sodic soils. In this case, the sodium saturation brings about the same effect as salinity, but the high pH dramatically affects the availability of micronutrients (low availability/solubility of micronutrient salts at these $\mathrm{pH}$ levels), the soil structure, and porosity (poor drainage, tendency for waterlogging, little oxygenation because of saturation of the exchange complexes in the soil by sodium). In the past, most studies have focused on salinity and only a few on sodicity. Despite the importance of salinity in crop production worldwide and the abundant knowledge on the effect of salinity on plant growth and development, there has been surprisingly little effort to breed for improved salinity tolerance, with the exceptions of wheat, rice, barley, alfalfa, and soybean. Breeding tolerant legume crop varieties is therefore urgently needed.

Besides terminal drought and salinity, high or low temperature drastically affects the grain filling in legumes (e.g., chickpea, lentil, pea) (Croser et al. 2003; Singla and Garg 2005). Waterlogging is another serious constraint affecting yield adversely in some legume crops such as soybean (Linkemer et al. 1998) and pigeonpea (Kumutha et al. 2008). Nitrogen $(\mathrm{N})$ and phosphorous (P) deficiencies are other common limiting factors for crop production in some legumes, especially in arable soils (Atkins et al. 1984; Schulze and Drevon 2005).

\section{B. Biotic Stresses}

The major biotic stresses affecting legumes are fungal diseases, although insects, nematodes, viruses, bacteria, and parasitic weeds can also drastically decrease legume production. Foliar diseases caused by biotrophic pathogens, such as rusts and downy and powdery mildews, are major limiting factors in legume production. The most important of these diseases are present in all areas where legumes are cultivated.

1. Fungal Diseases. Fusarium wilt, caused by Fusarium oxysporum, is one of the most serious fungal diseases, not only in legumes but also in many plant species (Beckmann 1987). The fungus infects through the roots and penetrates into the vascular system, with few symptoms on the root surface. The pathogen spreads throughout the plant, causing 
vascular discoloration, wilting, and death. This can result in substantial stand reduction and yield loss. In general, different Forma specialis of $F$. oxysporum are responsible for causing the Fusarium wilt in different legume crop species. For instance, $F$. oxysporum f. sp. ciceri causes wilt in chickpea, $F$. oxysporum f. sp. pisi in pea, F. oxysporum f. sp. tracheiphilum in cowpea and soybean, $F$. oxysporum $\mathrm{f}$. sp. phaseoli in common bean, and F. oxysporum f. sp. lentis in lentil. Fusarium udum is responsible for causing Fusarium wilt in pigeonpea. Fusarium wilt causes severe yield losses in different legume species.

Ascochyta blight, caused by Ascochyta sp., is another yield-reducing fungal disease in several legumes (Tivoli et al. 2006). For instance, in case of chickpea, Ascochyta rabiei is able to grow from the pod wall into the seed while it is still immature. It can be found in the seed coat or even in the cotyledons. A study has shown that $50 \%$ to $80 \%$ of seeds collected from pods with Ascochyta lesions were infected, but seed collected from healthy pods on the same plants were not infected. Spores can also contaminate the seed surface during harvest operations. Both deep and superficial seed infections transmit the disease to seedlings. The fungus sporulates on seeds as soon as they are planted in moist soil. Similarly, A. phaseolorum causes infection in cowpea, common bean, and soybean. In case of field pea, three Ascochyta species are responsible for Ascochyta blight complex. A. pisi and $A$. pinodes both cause lesions on leaves, stems, and pods that are difficult to distinguish from one another. Phoma medicaginis var. pinodella (synonym Ascochyta pinodella) is more common on stem bases than on leaves and pods. Ascochyta blight of lentil is caused by the fungus $A$. lentis. The fungus has a narrow host range and cannot cause disease on other pulse crops. Similarly, Ascochyta blight of chickpea, pea, or cowpea does not infect lentil.

Several rust species also infect grain and forage legumes, most of them belonging to the genus Uromyces, such as U. appendiculatus on common bean; $U$. ciceris-arietini on chickpea; $U$. pisi on pea; $U$. striatus on alfalfa; $U$. viciae-fabae on faba bean, lentil, and common vetch; and $U$. vignae on cowpea (Sillero et al. 2006). Also, rust species belonging to other genera can be major problems on legumes, such as Phakopsora pachyrhizi and $P$. meibomiae on soybean or Puccinia arachidis on peanut (Rubiales et al. 2002). Asian rust (Phakopsora pachyrhizi) is a severe disease that causes important yield losses in soybean and is spreading rapidly around the world (Carmona et al. 2005; Pivonia and Yang 2004; Du-Preez et al. 2005). Powdery mildew of pea has a worldwide distribution, being particularly important in climates with warm, dry days and cool nights, adversely affecting yield and quality. Severe 
infection may cause $25 \%$ to $50 \%$ yield losses (Warkentin et al. 1996). Downy mildew, caused by Peronospora viciae, occurs in most places where the crops are grown but is most frequent and severe in cool, maritime climates (Sillero et al. 2006).

Anthracnose, caused by Colletotrichum lindemuthianum, is most common bean disease that attacks the foliage and fruit of beans and causes serious yield losses in several parts of world. The disease is most common and severe on common bean but may also affect cowpea, lima bean, and faba bean. The anthracnose fungus infects leaves, stems, and pods of common bean plants. The most characteristic symptom of the disease is the black-red sunken cankers or spots that develop on infected pods. As these spots become older, the edges develop a black ring with a red outer border and may show pink ooze in the center, which contains the spores of the fungus. Similar spots may develop on seeds. Red-brown spots and streaks also develop on stems, petioles, and leaves.

2. Viral Diseases. Virus diseases are among the important biotic constraints for the production of many legume crops. For example, bean common mosaic virus (BCMV) and its close relative, bean common mosaic necrotic virus (BCMNV), are the most widespread and frequent viruses of common bean leading to significant losses. In addition, over the past two decades, bean golden mosaic virus (BGMV) has been considered the most important yield-limiting disease for bean production in parts of Central America and the lowlands of the Caribbean, with yield losses between 10\% and 100\% (Coyne et al. 2003). Pea seed-borne mosaic virus chiefly infects lentil. Members of the family Luteoviridae (luteovirids) such as soybean dwarf virus (SbDV) and beet western yellows virus (BWYV) appear to be very common in both chickpea and lentil (Tadesse et al. 1999; Abraham et al. 2002). Sterility mosaic disease (SMD) is probably one of the most important yield-reducing factors in pigeonpea (Kulkarni et al. 2002). Of the important biotic constraints specific to sub-Saharan Africa (SSA), peanut rosette disease (GRD) is endemic to the African continent and epidemics occur often throughout SSA, reducing peanut production and crippling rural food security (Naidu et al. 1999).

3. Insect Pests and Nematode Diseases. More than 200 species of insects feed on several legumes, of which pod borer (Helicoverpa armigera), spotted pod borer (Maruca vitrata), pod fly (Melanagromyza obtuse), pod sucking bugs (Clavigralla spp., Nezara viridula) and the bruchid (Callosobruchus spp.) are most important economically. In addition to the huge economic losses caused directly by the pests, 
several indirect costs arise from the deleterious effects of pesticides on the environment and human health (Sharma 2001).

The insect pests of major concern in chickpea and pigeonpea are pod borers ( $H$. armigera and $M$. vitrata) and podfly (Melanagromyza spp.). These insect pests feed on various plant parts, such as leaves, tender shoots, flower buds, and immature seeds. Few farmers in developing countries are able to spend precious income on chemical pest control. In these situations, there are serious concerns of the adverse effects of pesticides on the environment and all living organisms. It has been difficult to breed for Helicoverpa resistance in chickpea and pigeonpea because sources with a high level of resistance are not available in the cultivated species of these legumes (Sharma et al. 2005). Recent studies have shown the potential of utilizing the wild species for insect pest resistance breeding programs, as these species have shown higher levels of resistance (Sharma et al. 2005; Dwivedi et al. 2007; Mallikarjuna et al.2007).

Cowpea is highly susceptible to flower thrip during budding and early flowering, when they can cause flower abortion and pod distortion (Frei et al. 2005). Flower thrip damage in cowpeas starts at preflowering; when nymphs and adults may attack the terminal leaf buds and bracts/stipules, causing the latter to become deformed with a mottled brownishyellow appearance. However, the main attack is on the flower buds and flowers. Infested buds appear dried and brown and may eventually abort, leaving dark red scars. In case of common bean, leafhoppers, white flies, bean pod weevils, and bean beetles cause severe damage in the field, and bean weevils can be a problem during storage.

Plant parasitic nematodes are serious production in some legume crops. For instance, the soybean cyst nematode (SCN), Heterodera glycines, has long been recognized as a globally significant pest in nearly all soybean regions, including North America, Indonesia, Japan, Korea, China, and South America (Riggs and Niblack 1999). Soybean production losses due to SĆN are significant and may be above 3 million metric tons globally (Wrather et al. 1997). Infection causes significant root damage and often can result in plant stunting and yellowing. Nematode cysts can remain in the soil for more than 10 years. Resistance to SCN is quantitative in nature (Mansur et al. 1993), making it difficult to assay in a field setting. Bioassays can be challenging and costly in greenhouse and growth chamber systems as well.

\section{GENOMIC RESOURCES IN LEGUMES}

Although several of the above-mentioned constraints that limit grain legume production or quality have been addressed by conventional 
breeding and enhanced management, the success has been variable. In such situations, there is a hope that the use of genomics tools will help to address these problems. Molecular markers and molecular genetic linkage maps are the prerequisites for genomics-enabled crop improvement (Dwivedi et al. 2003, 2006; Varshney et al. 2005). Among different legumes, Medicago, Lotus, and soybean have had significant investment toward developing genomic resources including genome sequencing. In case of other legumes, especially tropical legumes, the progress in the area of genomics has been very slow until recently. Even today some legume crops such as pigeonpea either do not have any appropriate marker repertoire or lack genetic maps. Nevertheless, as a result of advances in sequencing and genotyping technologies and also due to several international collaborations, this situation is changing in several legume crops (see Varshney et al. 2009b).

\section{A. Genome Sequencing for Understanding Genome Architecture}

There are more than 730 genera and 19;400 species in the Fabeaceae, of which only a handful have been domesticated as crops. Genome sequencing in the legumes has been in two relatively closely related groups of the Papillionoid legumes: soybean (Glycine max) in the Phaseoleae group and Medicago truncatula and Lotus japonicus in the Galegoid group (Doyle et al. 2000). These two groups, Phaseoloid and Galegoid, represent most of the crops species in the legumes except for peanut and a few others.

The sequencing of the Lotus and Medicago genomes began about the same time, and both were done as models for symbiosis and nitrogen fixation and because they both had relatively small nuclear genomes (Young et al. 2005). Although they began about the same time, the approaches for sequencing differed somewhat between these two genomes.

Lotus was sequenced initially by the Kazusa DNA Research Institute (Japan), using a modified bacterial artificial chromosome (BAC)-by-BAC approach followed by draft sequencing of selected regions of the Lotus genome, also via BACs (Sato et al. 2008). The sequencing project began using a BAC-by-BAC approach from seed points, often genes or genetic markers, from which the sequencing would walk out along a BAC tiling path. Later, to increase speed and cut costs, researchers switched to targeted sequencing of BAC pools combined with some reduced representation whole genome shotgun sequencing. This is a grossly simplified explanation of the approach employed, but the end result is that it is predict that they recovered nearly $91 \%$ of the gene space of Lotus.

Medicago genome sequencing has proceeded via a traditional BAC-byBAC approach but focused solely on the euchromatic part of the genome, 
which should also be its gene-rich part. This portion of the genome was first determined cytologically (Kulikova et al. 2001), but due to the lack of precision in estimating DNA packaging and meiotic chromosome lengths, this number has increased over the course of the sequencing project. Initially, the BACs were sequenced to a level similar to rice and the human genome, but as the euchromatic genome size increased, the project switched to a level of draft of sequencing of individual BACs (http://medicago.org/genome/genome_stats.php). The end result of this project, which should be published in 2009 , will be a genetically and physically integrated sequence map of most of the euchromatin of the Medicago genome and should capture greater than $90 \%$ of the genes.

Both Medicago and Lotus used some type of BAC-by-BAC approach, also called the traditional sequencing method, as was used for the human genome. Other sequencing approaches include. whole genome shotgun (WGS) as was done for several species of Drosophila (Consortium 2007), a human genome (Venter et al. 2001), and many bacterial genomes. This approach is powerful and fast but has been problematic for larger, complex plant genomes, as repeated sequences in large genomes can complicate the correct assembly and ordering of the pieces. The soybean genome was recently sequenced using a shotgun approach (www. phytozome.net/soybean). Despite the concern over the large complex, duplicated genome (Schlueter etal. 2007), it appears to have assembled well. There are pseudomolecules representing each of the 20 linkage groups.

Other types of genome sequence information are beginning to emerge for other legume crops. This sequence information is often not complete but rather snapshots or pieces of the genome. For example, the cowpea genome has been sequenced using an approach that samples the hypomethylated portion of the genome by methylation filtration (MF), providing over 250,000 gene-space sequence reads (GSRs) with an average length of 610 basis points (bp) representing about $160 \mathrm{Mb}$ of sequence information (Timko et al. 2008). This type of approach can enrich gene sequences rather than sampling everything in the genome randomly but does not result in a sequence that can be assembled.

\section{B. Species-Specific Genomic Resources}

Advances in genomics research of Medicago, Lotus, and soybean opened the doors for comparative genomics to use the maker or sequence information from these species to other temperate and tropical legume species, and comparative maps were developed (Choi et al. 2004b; Zhu et al. 2005). However, as the majority of the food legume crops suffer from a low level of diversity, especially in the cultivated gene pools, 
markers coming from other legume species could were not very useful for assaying the polymorphism, developing dense genetic maps, or mapping the traits. Therefore, there is a need for developing species-specific genomic resources in several grain legume crops at international level.

1. Molecular Markers. Among the different marker systems currently available, simple sequence repeats (SSR) and single nucleotide polymorphism (SNP) marker systems have emerged as markers of choice for plant breeding applications (Gupta and Varshney 2000; Varshney et al. 2007). While SSR markers can be assayed in low-tech laboratories, SNP assays need sophisticated genotyping platforms or can be outsourced (Varshney et al. 2009b). Therefore, availability of SSR markers for a legume species will be very useful for the breeding community for wider applications.

For development of SSR markers, three approaches are being used:

1. Isolation of SSRs from genomic DNA libraries (Gupta and Varshney 2000)

2. Mining ESTs or gene sequence data (Varshney et al. 2005)

3. Mining the BAC-end sequences (discussed later)

Until recently, SSR markers were developed using the genomic DNA library approach. As a result, only a few hundred SSR markers were available in these legume species (Varshney et al. 2007). As these legume crops have low levels of polymorphisms, the SSR markers available were not sufficient to develop good genetic maps. However, due to recent advances in sequencing technologies (Gupta 2008; Hudson 2008), a larger number of ESTs have become available (Varshney et al. 2009b), and these are being used to mine for SSRs (Varshney et al. 2005). Similarly, a large number of BAC-end sequences have been generated. for several legume species (see Varshney et al. 2009́b) that have also been useful for mining the SSRs (Mun et al. 2006; Shultz et al. 2007). Isolated or identified SSRs are being used to converting them into markers at several labs (e.g., ICRISAT for chickpea, pigeonpea, and peanut; University of California-Davis for cowpea, pigeonpea, and chickpea; University of Georgia, Catholic University (Brazil), and Empresa Brasileira de Pesquisa Agropecuária (EMBRAPA, Brazil) for peanut; Centro Internacional de Agricultura Tropical (CIAT, Colombia), and Purdue University for common bean). As a result, several thousand SSR markers have become available for several of these legume species (see Varshney et al. 2009b). Some legume crops such as lentil and faba bean, however, still lag in developing SSR markers. 
As SNP markers have become more popular due to their highthroughput in a cost-effective way for using them in association genetics, several research groups are actively engaged in developing high-throughput SNP genotyping platform. For instance, a custom 384-SNP GoldenGate assay has been designed in soybean using SNPs that had been discovered through the resequencing of five diverse accessions that are the parents of three recombinant inbred line (RIL) mapping populations (Hyten et al. 2008). Very recently, the University of California-Riverside developed a GoldenGate assay for genotyping 1,536 SNPs in case of cowpea (T.J. Close, pers. commun). Significant efforts have been invested at the University of California-Davis to develop assays for genotyping 768 SNPs to 1536 SNPs in four tropical legumes (chickpea, pigeonpea, common bean, and cowpea (Doug Cook, pers. commun). Similar efforts are under way as collaborative efforts of the University of Georgia, University of California-Davis (both U.S.) and Catholic University (Brazil) to develop SNP assays for $\mathrm{AA}$ and $\mathrm{BB}$ genome species of peanut. It is expected that soon the majority of these legume species will have larger number of SSR markers and high-throughput SNP assays that will overcome the problem of identifying a sufficient number of polymorphic marker loci required for genome mapping and trait association studies.

2. Genetic Maps. Although development and/or use of molecular markers started in many of these legume species sometime in the 1990s (Keim et al. 1990; Fatokun et al. 1992; Nadimpalli et al. 1994), progress in developing genetic maps in the majority of these legume species has been very slow. As mentioned earlier, narrow genetic diversity in gene pools of these legume species in general and paucity of polymorphic markers in particular have been main constraints. Due to availability of larger number of markers in these legume species during last two to three years, progress has accelerated in developing genetic maps for several legume species, such as peanut (Varshney et al. 2009a) and chickpea (Nayak et al. unpublished). A few important genetic mapping studies in legumes are listed in Table 6.2.

3. BAC Libraries and Physical Maps. Large insert libraries, such as bacterial artificial chromosome libraries, are very important for developing the local/genome-wide physical maps for cloning the gene(s)/ quantitative trait loci (QTL) of interest (Salvi and Tuberosa 2005) or undertaking genome sequencing (Jackson et al. 2006). Although BAC libraries were available only for few legume crops until recently, the University of California-Davis has developed deep coverage (ca. 10 


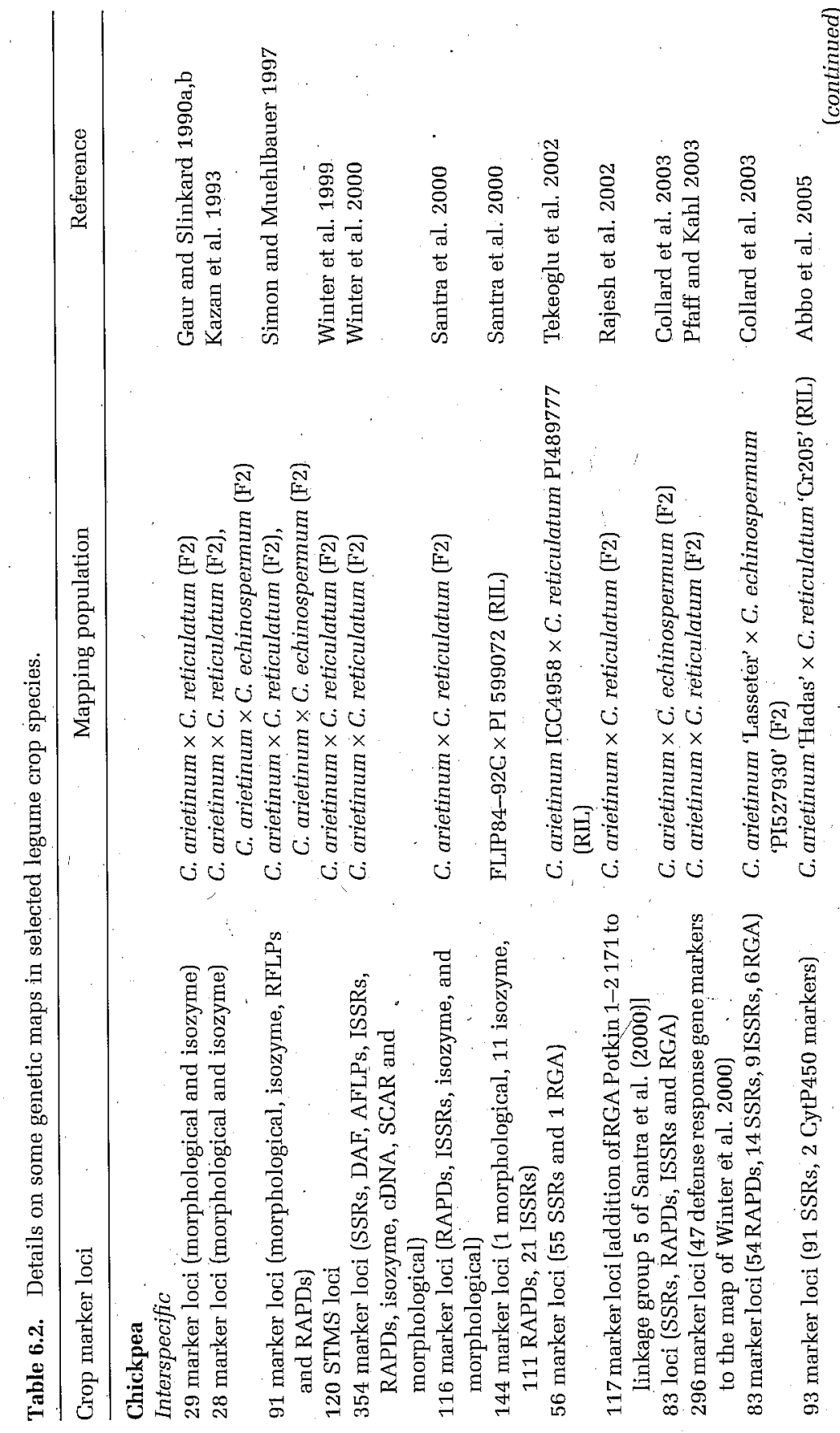




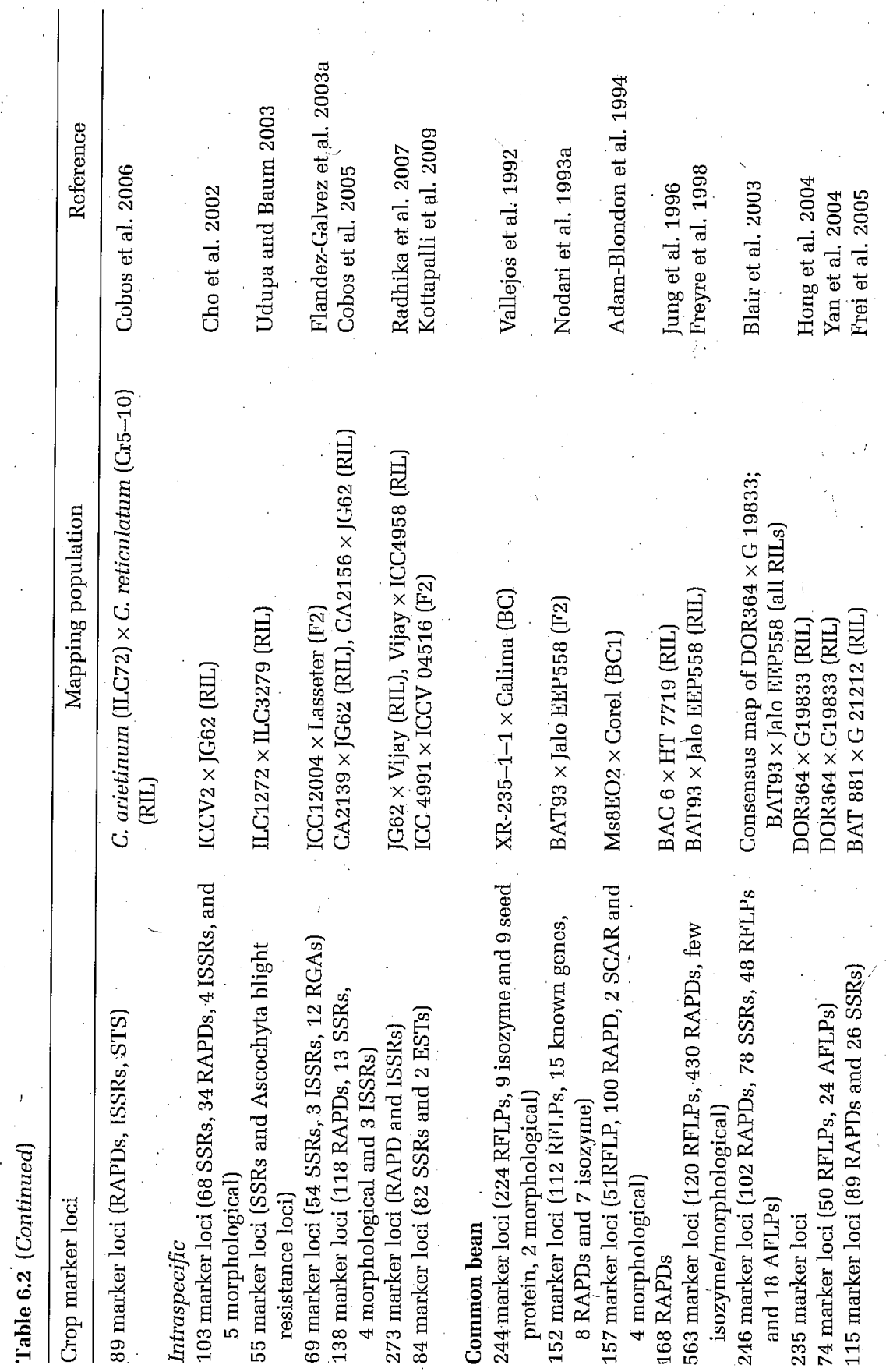




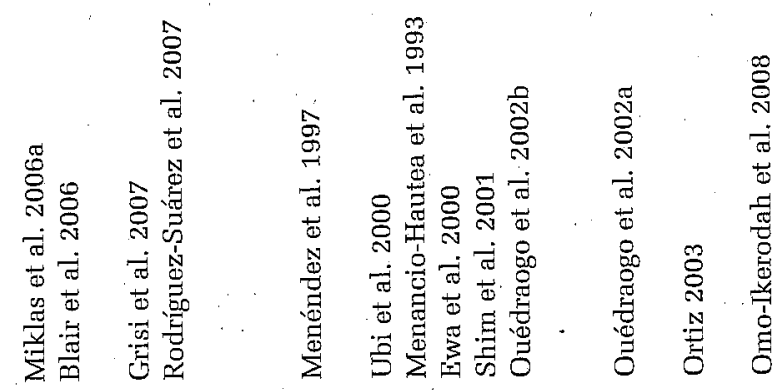

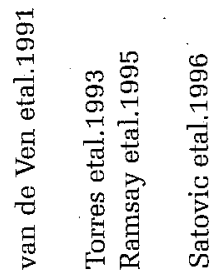

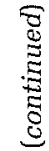
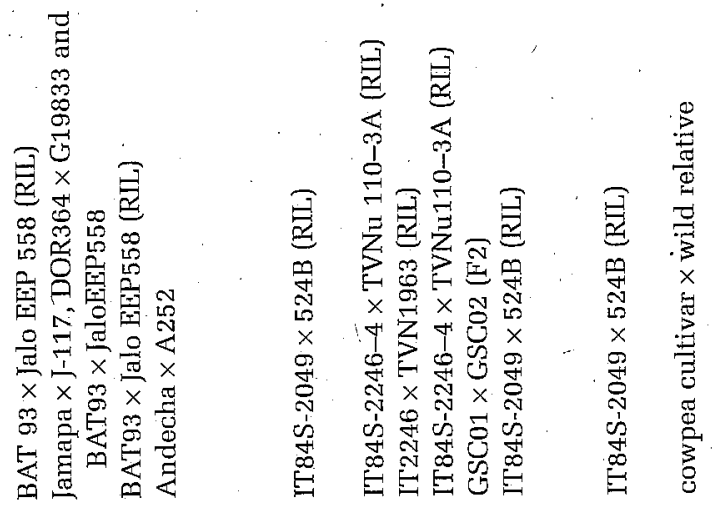

$\sum_{\overline{1}}^{\infty}$
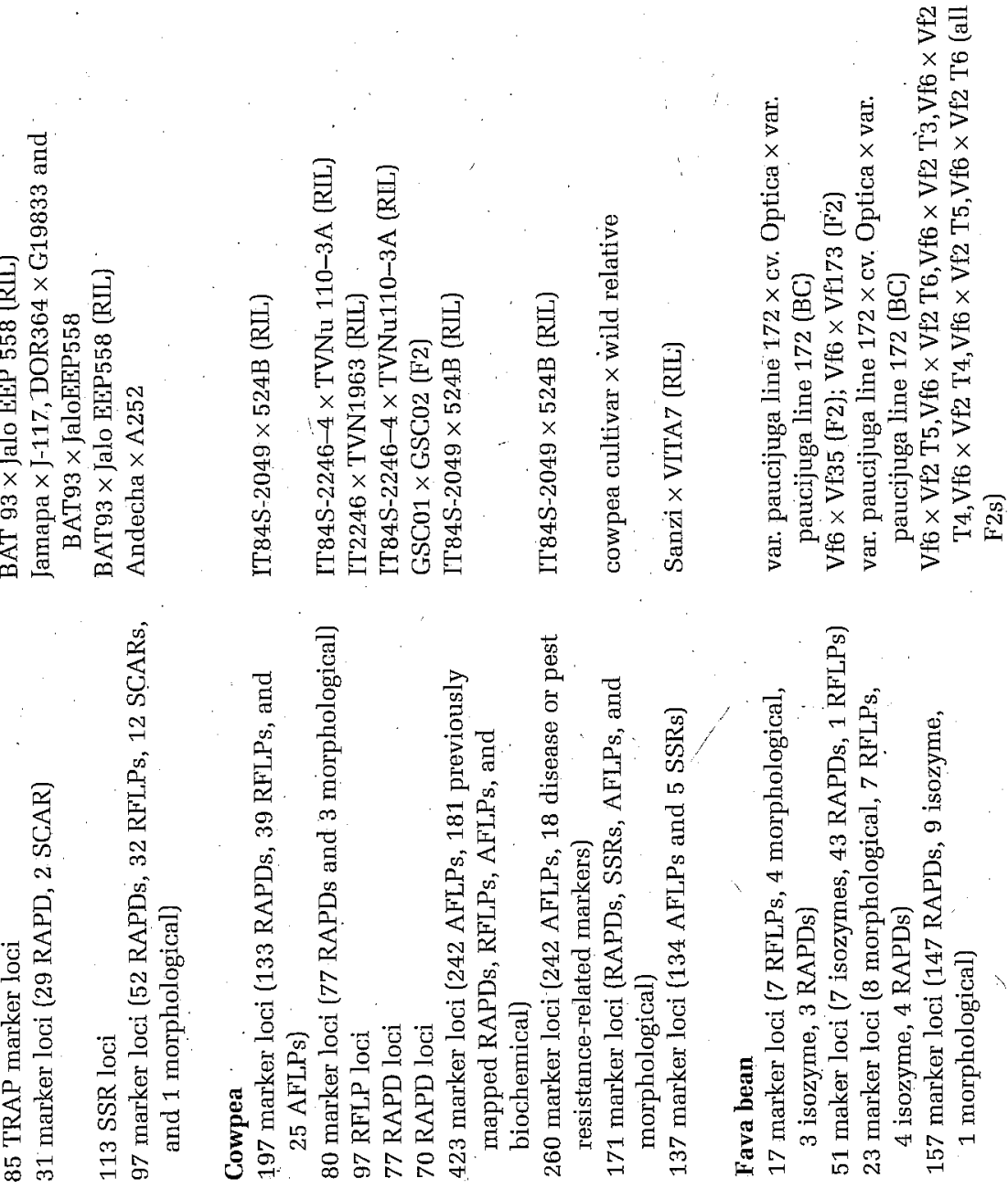


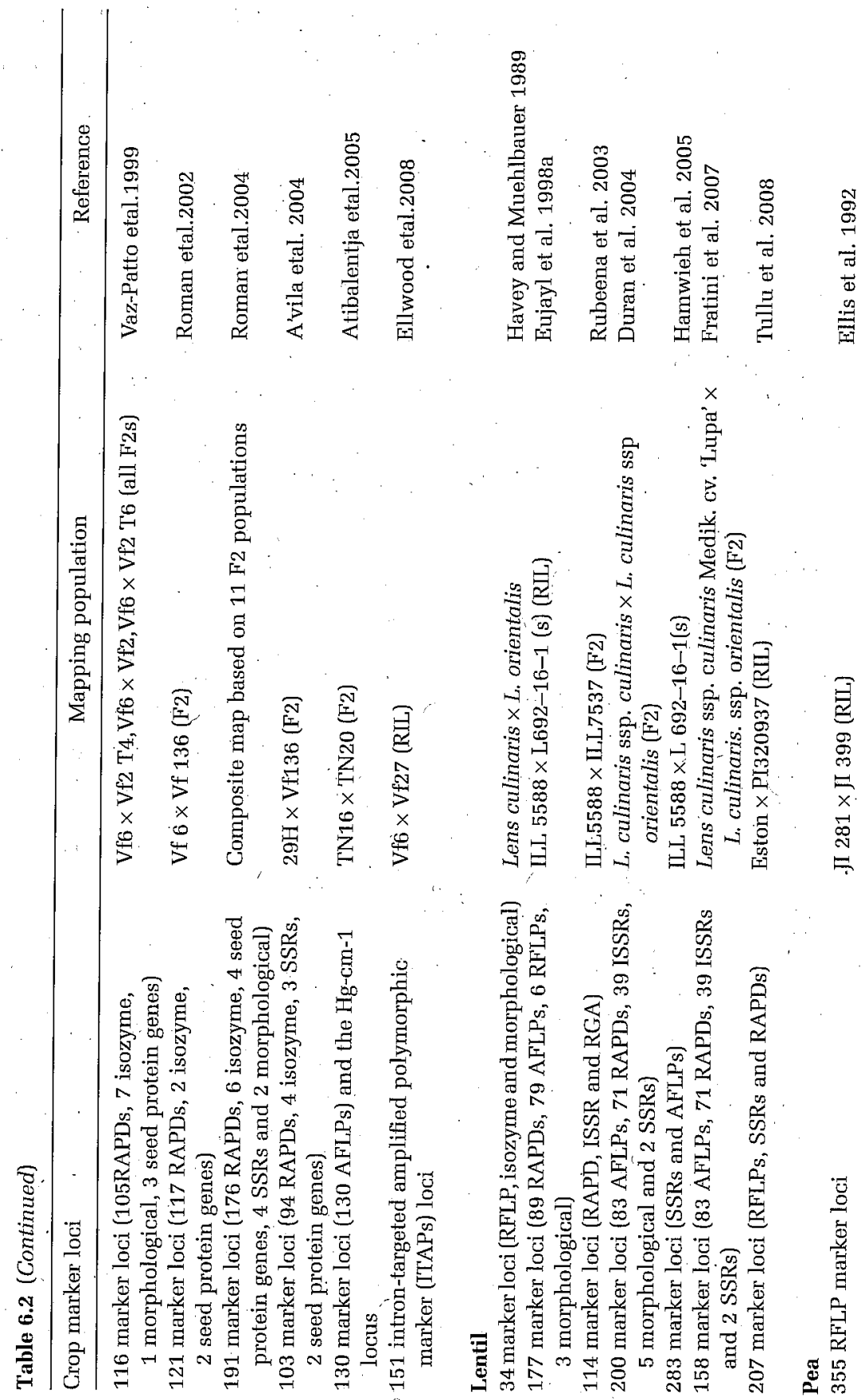



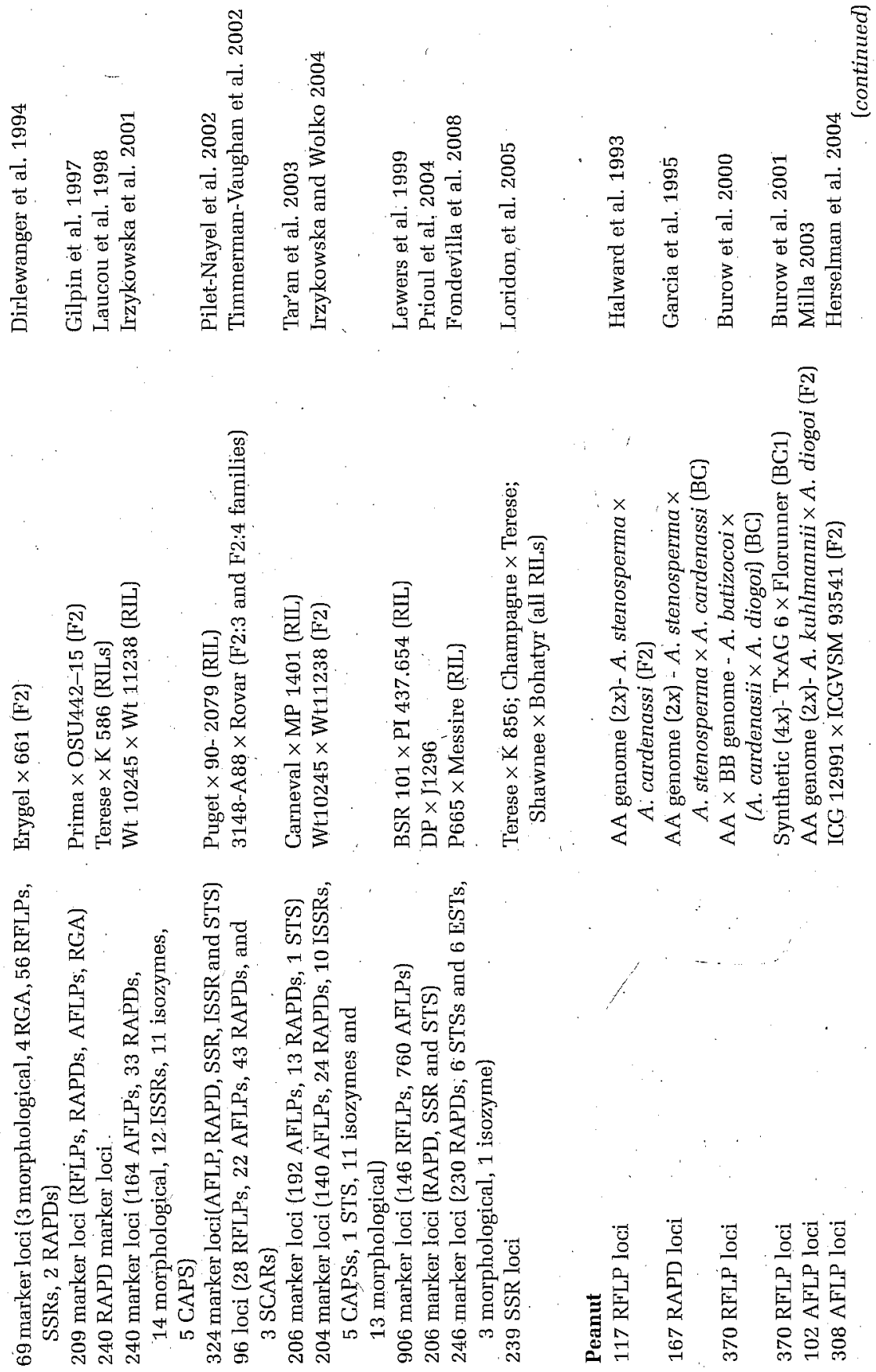


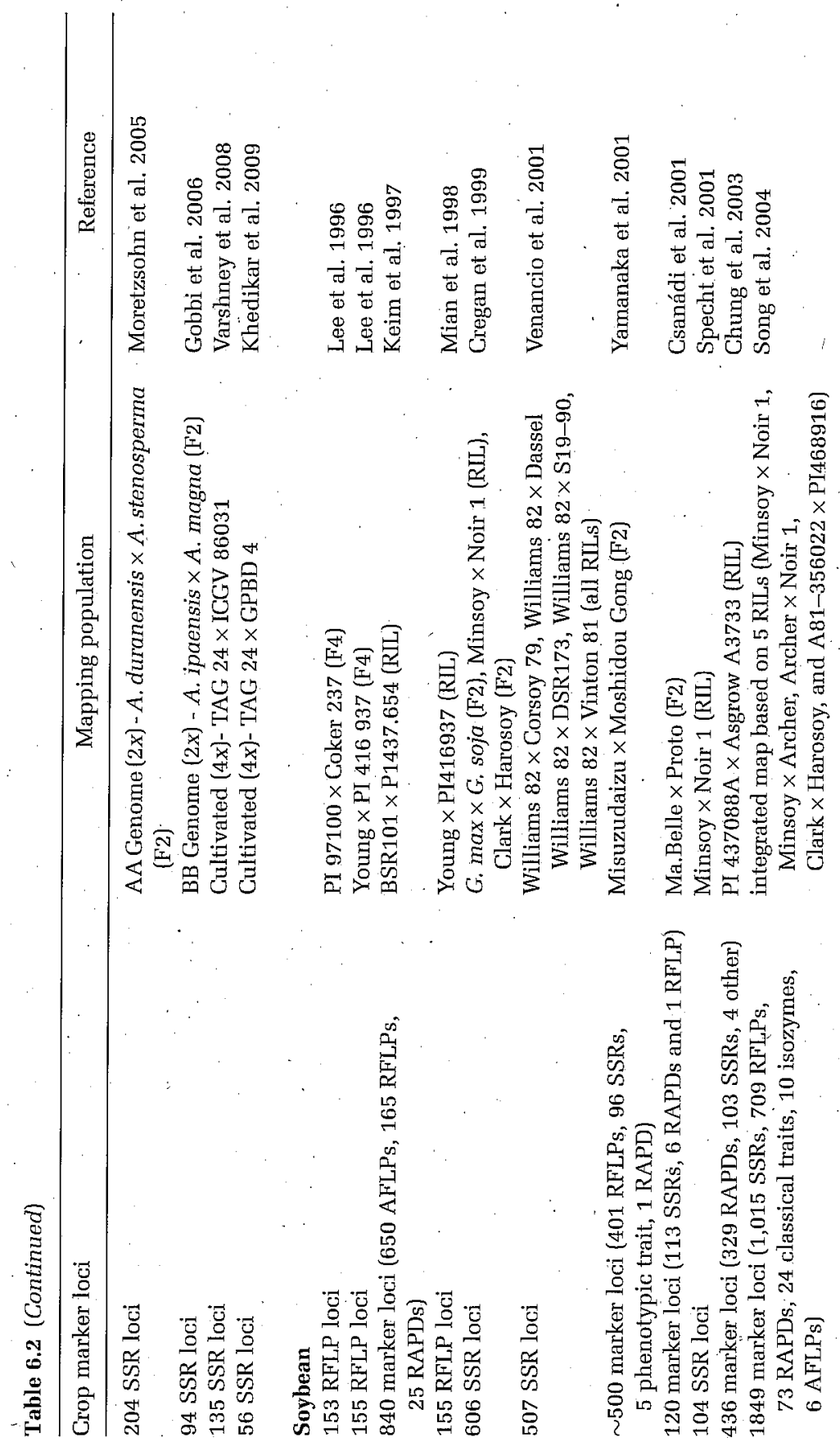




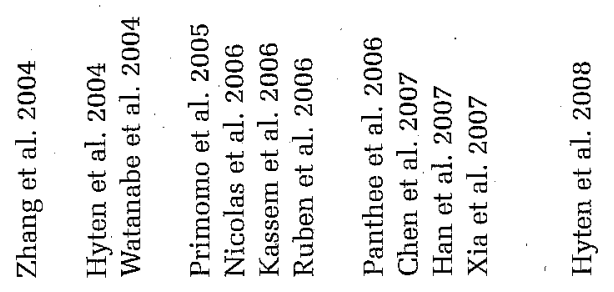
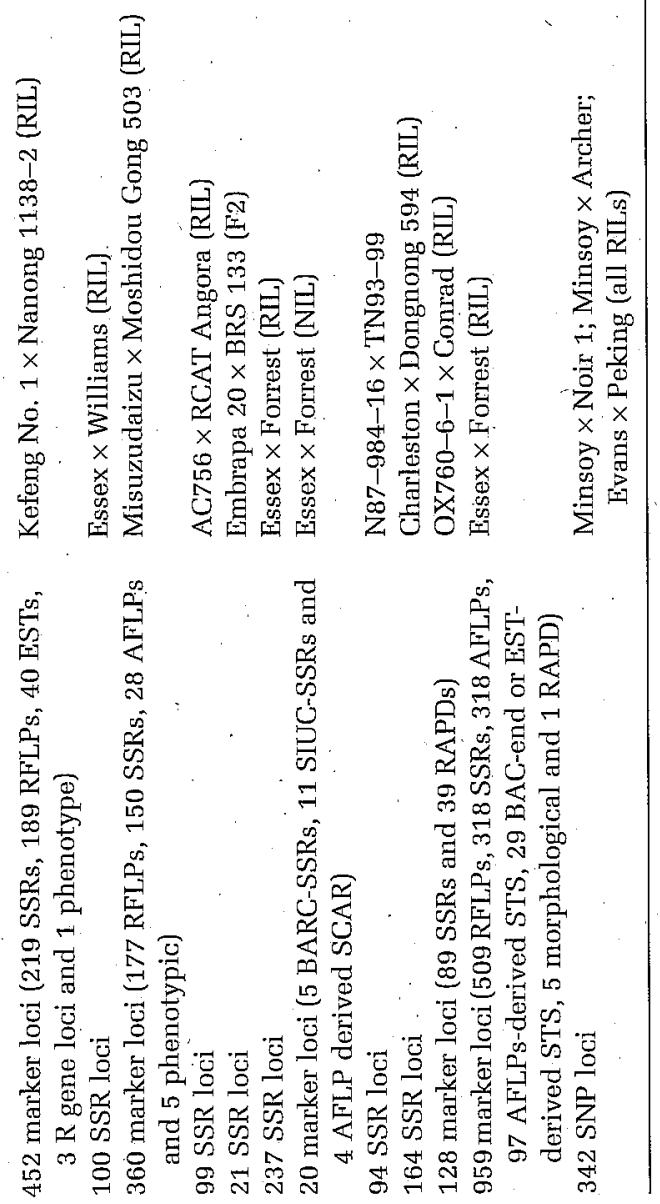
times) BAC libraries in several legumes (chickpea, pigeonpea, cowpea, and peanut). Furthermore, BAC-end sequences have been generated for 25,000 to 50,000 BACs in these legume species (D.R. Cook, pers. commun). The BAC-end sequence data are being analyzed for getting the insights of genomes of these legume species (Foster-Hartnett et al. 2001; Schlueter et al. 2008) and for developing markers, such as SSRs, that would be very helpful to link the genetic and physical maps (Shultz et al. 2007).

In some legumes such as common bean and cowpea (excluding Medicago, Lotus and soybean), genome-wide physical maps also have been developed. For instance, fingerprinting of 41,717 BACs of common bean provided a draft physical map consisting of 1,183 clone contigs and 6,385 singletons with about 9 times coverage of the genome of common bean (Schuleter et al. 2008). Similarly in case of cowpea, based on high information content fingerprinting (HICF) of 60,000 BAC clones, a 10 times physical map of cowpea has been developed at the University of California-Riverside (T.J. Close, pers. commun). It is planned to anchor the cowpea physical map to the SNP-based genetic linkage map. Local physical maps for resistance gene homologs are also being developed in cowpea, pigeonpea, chickpea, and common bean at the University of California -Davis (see Varshney et al. 2009). It is anticipated that these physical maps will lead to sequencing of gene space or regions of interest very soon.

4. Transcriptome Resources. Recent years have witnessed significant progress in the area of transcriptomics in legumes other than Medicago, Lotus, and soybean. Until recently, it was difficult to imagine undertaking functional genomics in these legume species except model legume species and soybean. Nevertheless, the availability of genomic resources and recent technology advances have made it possible in a practical sense in several other legume species (Coram et al. 2007).

Among plant species, much work has been done in the development of functional genomics resources such as ESTs and array development has been done in cereal crops and model legumes. For instance, hundreds of thousands ESTs are available in model and major legume species (see Varshney et al. 2009b). Due to the availability of next-generation sequencing technologies such as $454 / \mathrm{FLX}$ and Solexa $1 \mathrm{~Gb}$ Sequencing, large numbers of ESTs have been developed very recently. For instance, using 454/FLX sequencing on the normalized complementary deoxyribonucleic acid (cDNA) pools collected from more than 20 different tissues representing a variety of plant developmental stages of chickpea 
and pigeonpea provided 435,184 and 496,705 sequence reads for each, respectively. The average length of sequence reads in chickpea is $236.4 \mathrm{bp}$ and $200.3 \mathrm{bp}$ in pigeonpea. Analysis of these sequence data should provide good transcriptome assemblies for chickpea and pigeonpea that can be used to analyze the gene contents as well as marker discovery.

Although several transcript profiling studies have been undertaken in Medicago, Lotus, and soybean with an aim at identifying genes involved in nodule and seed development (Thibaud-Nissen et al. 2003; Benedito et al. 2008; Combier et al. 2008), a few studies have been targeted in some other legume species to identify genes involved in resistance/tolerance to biotic and abiotic stresses (e.g., Irsigler et al. 2007). For instance, a small array with 768 features has been developed in chickpea (Coram and Pang 2005a). This array has been used to identify genes involved in Ascochyta blight resistance (Coram and Pang 2005b, 2006) and tolerance to drought, cold, and salinity (Mantri et al. 2007). In the case of cowpea, by using RNA as a surrogate for DNA of cowpea with a readily available soybean genome array, $11 \%$ to $14.7 \%$ of all probe sets on the array showed "present" calls (Das et al. 2008). These researchers enumerated 1,058 potential singlefeature polymorphisms (SFPs) between two parents of a RIL population. segregating for several important traits. Sequencing of 25 putative polymorphism-containing amplicons yielded a SFP probe set validation rate of $68 \%$. This study provides an example of extension of genomic resources from a well-supported species like soybean to orphan crops such as cowpea and pigeonpea.

\section{TRAIT MAPPING AND MARKER-ASSISTED SELECTION}

Molecular markers are powerful diagnostics tools used to detect DNA polymorphism both at the level of specific loci and at the whole genome level (Azhaguvel et al. 2006). As compared to morphological traits or markers, molecular markers have several advantages as they are phenotypically neutral and are influenced neither by environments nor by pleiotropic and epistatic interactions, and their expression is not dependent on plant age or part (Jones et al. 1997). In fact, the use of molecular markers in improving efficiency in plant breeding was suggested as early as in 1989 (Tanksley et al. 1989; Melchinger 1990). In this regard, once linkage between a gene for the agronomic trait of interest and marker locus is established, DNA diagnostic tests can be used to 
guide plant breeding (Morgante and Salamini 2003; Gupta and Varshney 2004). The selection of useful lines for breeding with the help of linked molecular markers is called marker-assisted selection (MAS). Use of MAS is especially advantageous for traits with low heritability where traditional selection is difficult, expensive, or lacks accuracy or precision.

The use of MAS in plant breeding has revolutionized the improvement of temperate field crops (Koebner and Richard 2002; Varshney et al. 2006) and will have similar impacts on breeding of legume crops, particularly for traits where phenotyping is possible only late in the season and where screening of traits is difficult or prohibitively expensive. Among different legumes, soybean was the first legume crop where MAS was used for breeding for soybean cyst nematode. Two SSR markers (BARC-Satt309 and BARC-Sat_168) identified by Cregan et al. (1999) have proven highly effective in identifying lines carrying SCN resistance from those carrying the allele for SCN susceptibility at the rhg1 locus.

Although a number of genes and QTL have been tagged using different kinds of molecular markers in several legume crops (Table 6.3), only a few markers have been validated and deployed in breeding programs (mainly in soybean and common bean). Indeed, soybean is the first legume crop where markers associated with several traits have been in use in MAS for a long time in both the public sector (Saghai Maroof et al. 2008) and the private sector (Cahill and Schmidt 2004). Because of the importance of soybean for the private sector, significant progress has been made in MAS in soybean breeding in the public sector. This is reflected in a press release of Pioneer Hi-Bred International Inc. in 2005: "Pioneer has led the development of patented processes for using MAS in soybeans," said John Soper, director of soybean research of this seed. company (www.pioneer.com/web/site/portal/menuitem.f644671720b9 4a9724d533d0d10093a0/). "The technology has allowed researchers to see things that were not possible to see and capitalize on a decade ago. Before MAS, breeders were limited to using visual observations and yield data to evaluate varieties and make selections. With MAS, Pioneer scientists now are able to understand the genetic basis for what they are seeing and use this knowledge to design and select better varieties." "MAS has been applied in some soybean breeding programs of the public sector as well. For instance, Saghai Maroof et al. (2008) have pyramided respective Rsv genes for soybean mosaic virus (SMV) from different loci (Rsv1, Rsv3, and Rsv4) in a susceptible cultivar 'Essex' through MAS. They found two-gene and three-gene isolines of Rsv1Rsv3, Rsv1Rsv4, and Rsv1Rsv3Rsv4 acted in a complementary manner, conferring 


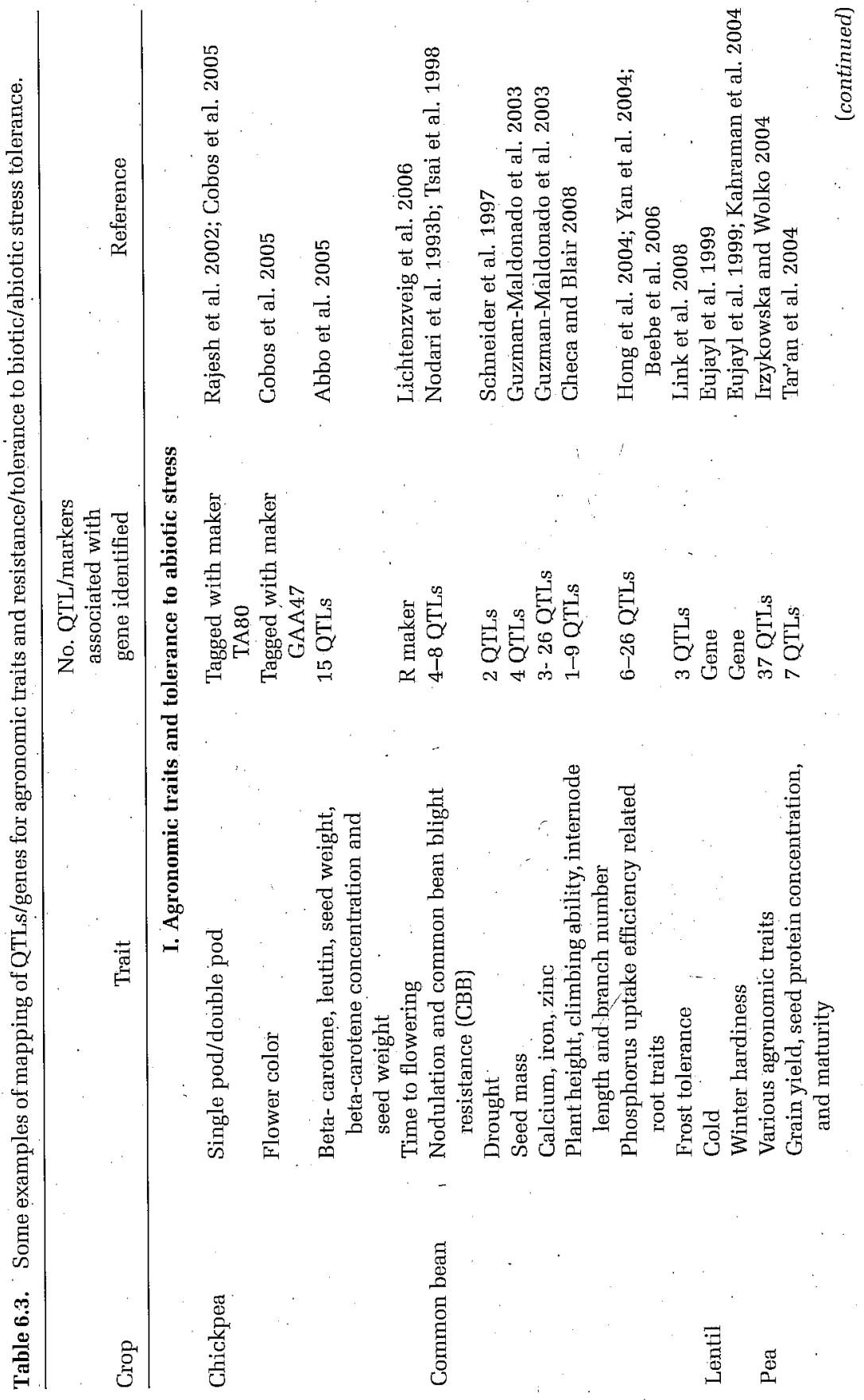




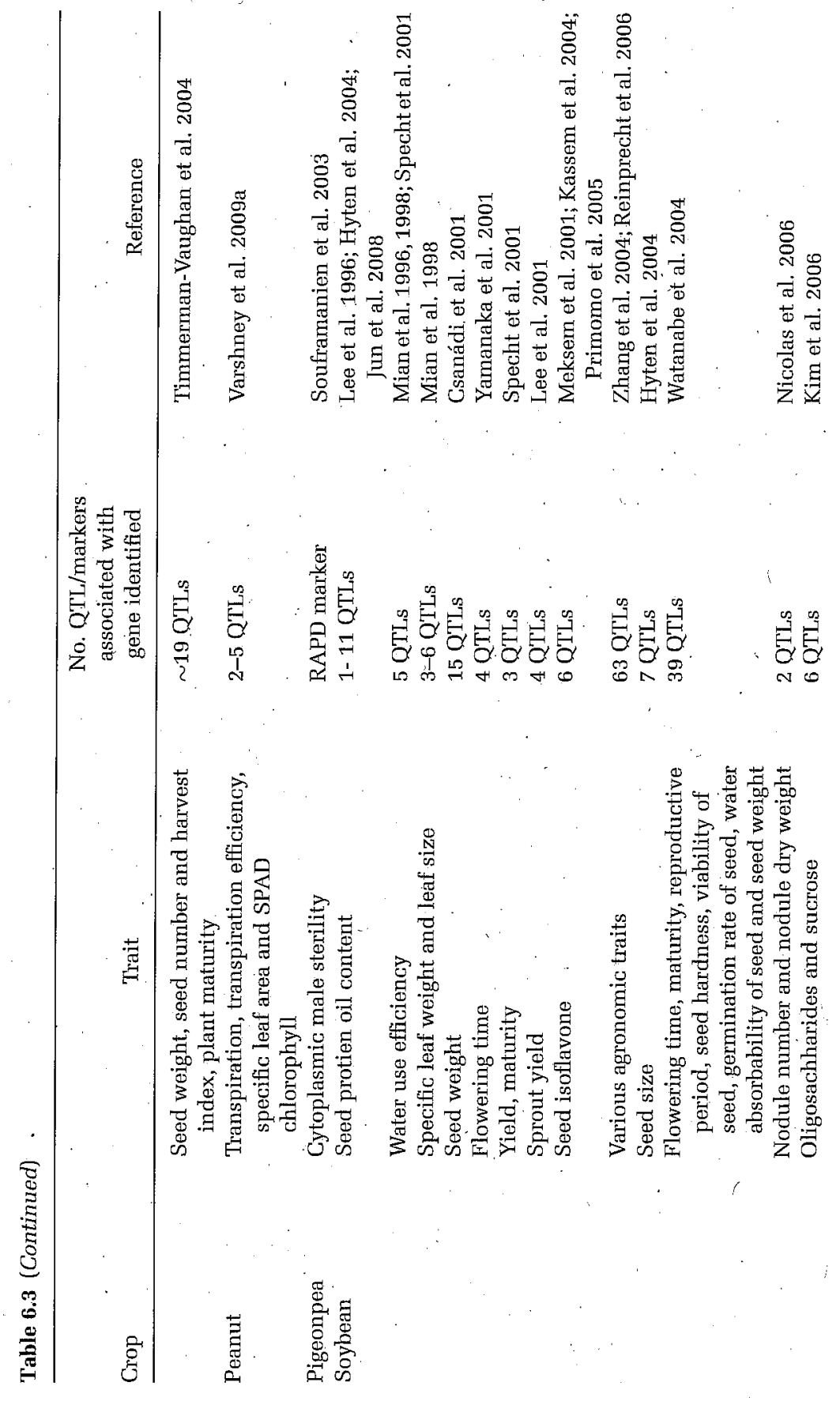




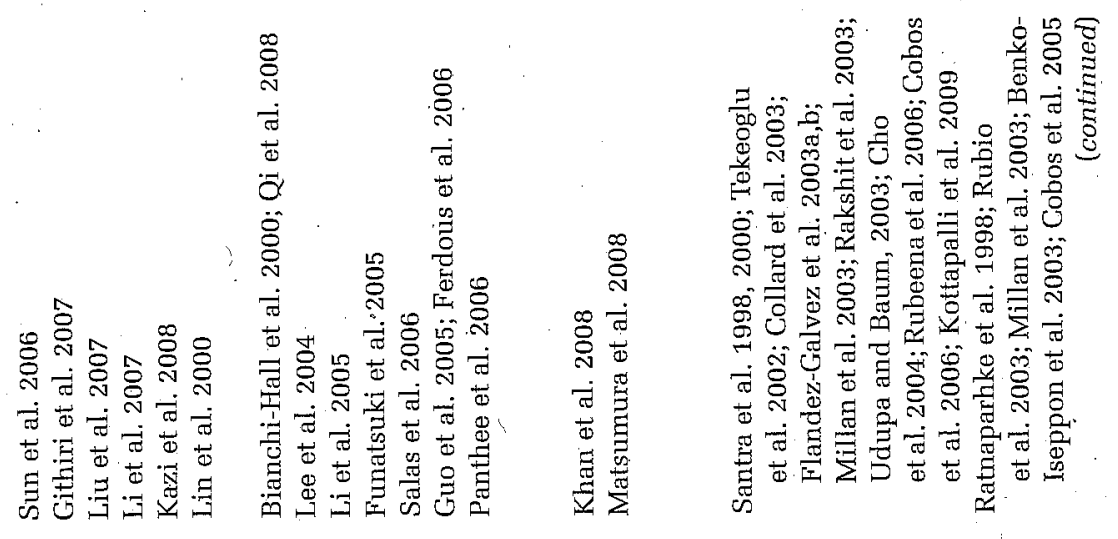

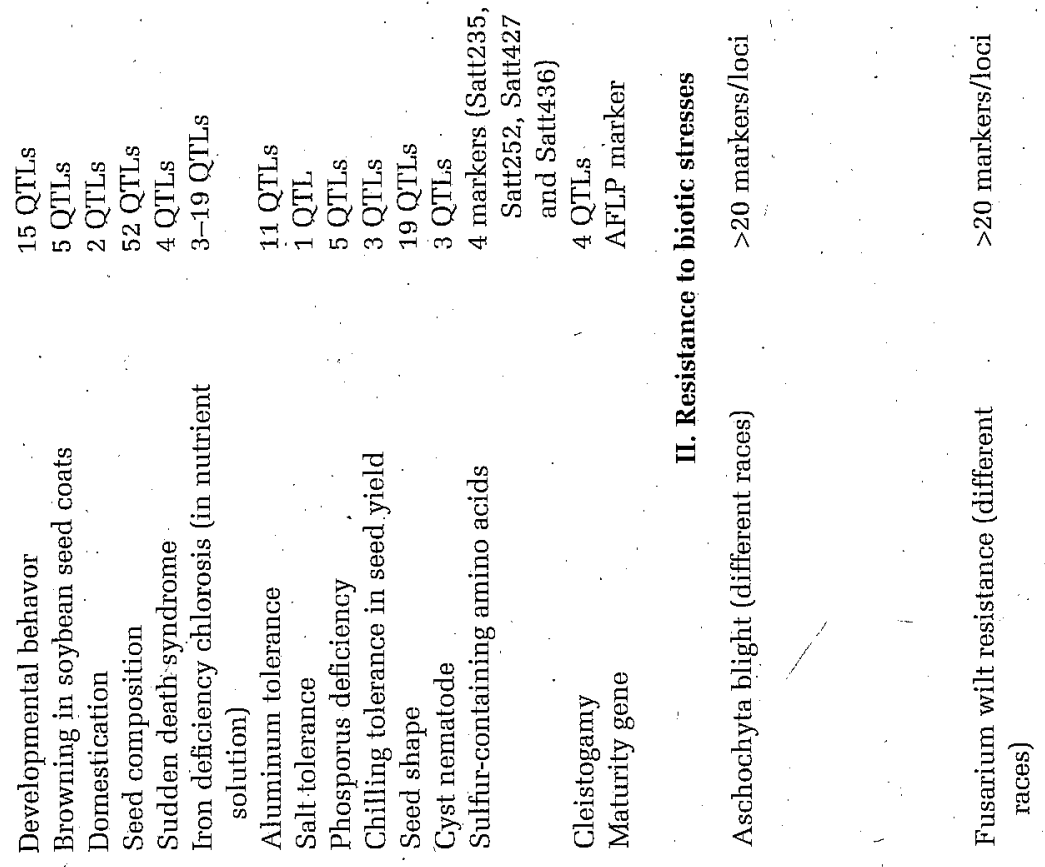

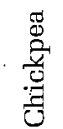




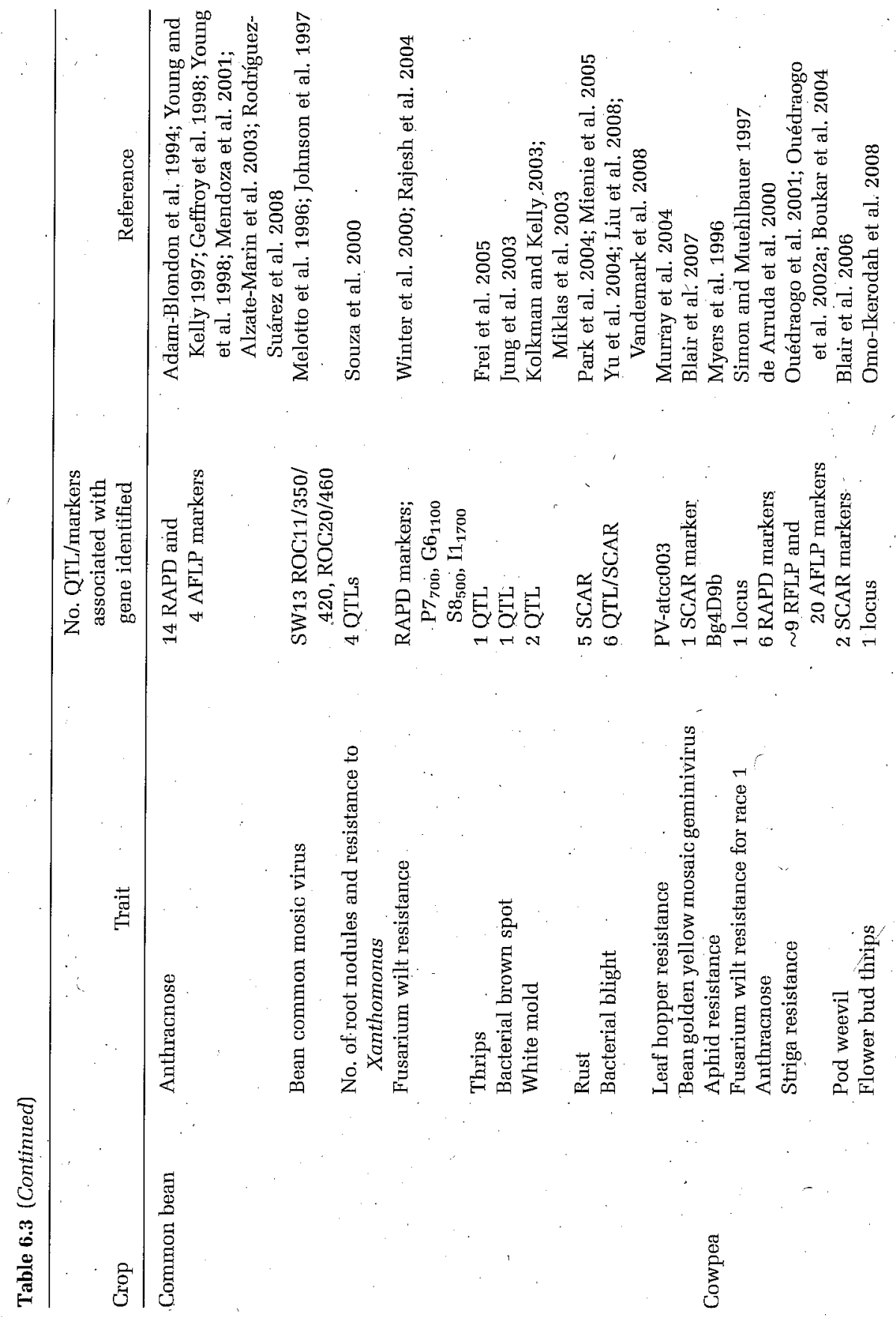




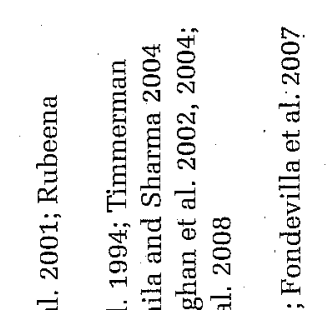

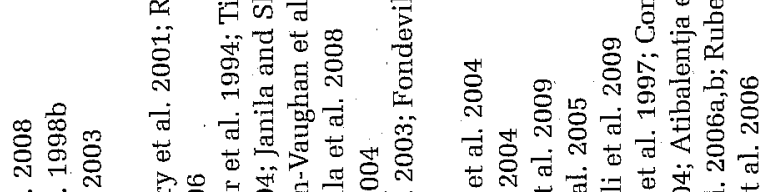

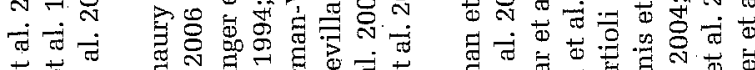

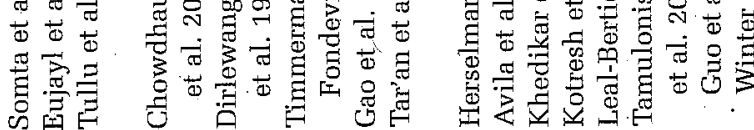

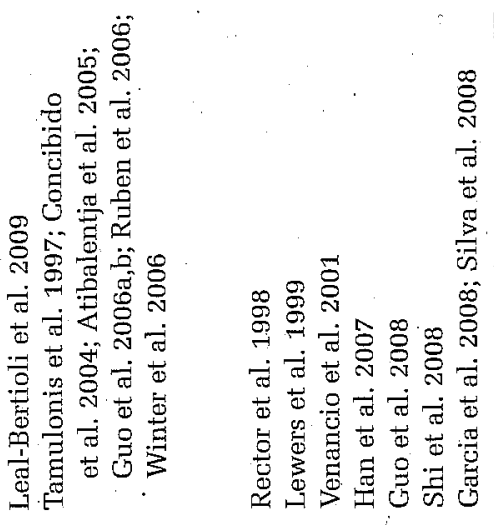

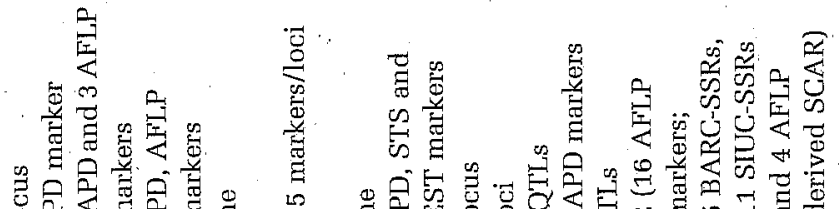

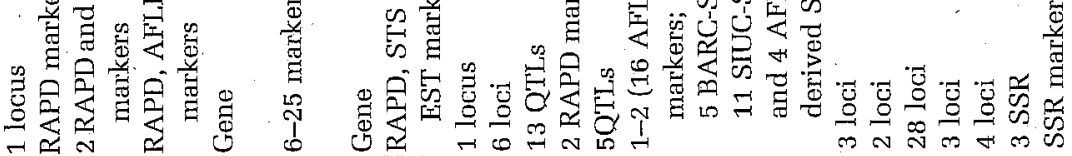

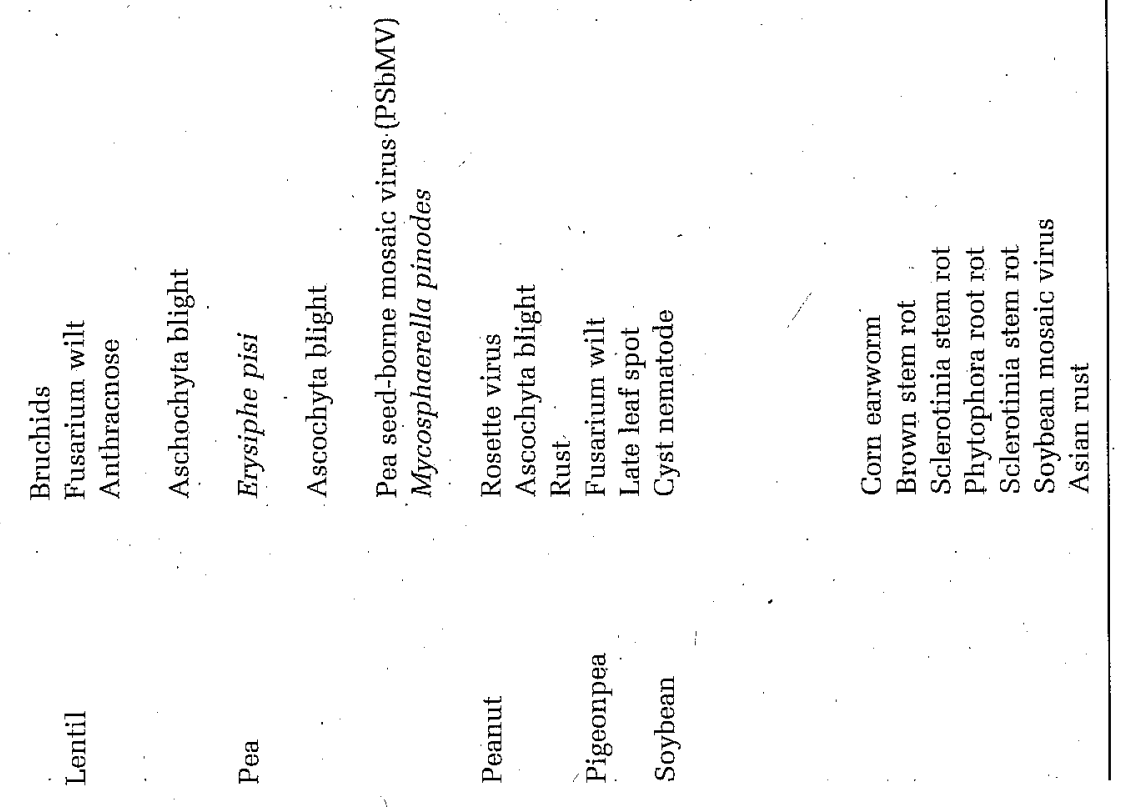


resistance against all strains of SMV, whereas isolines of Rsv3Rsv4 displayed a late susceptible reaction to selected SMV strains. In the case of common bean, a few reports are available on MAS deployment (see Miklas et al. 2006a,b). For example, MAS has been used successfully to breed for enhanced resistance to anthracnose in the cultivar 'Perola' in Brazil (Raganin et al. 2003), pinto beans in the United States (Miklas et al. 2003), and Andean climbing beans in Mexico/Colombia (Garzón et al. 2008). Although efforts for validating and deploying markers in MAS are under way for root traits in chickpea at ICRISAT or for host plant resistance to striga in cowpea at the International Institute of Tropical Agriculture (IITA, Nigeria), there is a need to speed up marker validation and deployment in breeding programs in different legumes.

\section{SUMMARY AND PROSPECTS}

During last five years or so, significant progress has been made in developing genomic resources in model species (Medicago, Lotus), major legumes (soybean, common bean, peanut), and so-called orphan (cowpea, chickpea, pigeonpea).legume crops. For instance, legume crops now enjoy the availability of reference/draft genome sequences (soybean, Medicago, Lotus) and dense genetic as well as physical maps. Availability of an appropriate amount of molecular markers is also no longer a bottleneck in many legume species. Nevertheless, there is still a need to develop critical mass of molecular markers and good genetic maps in some minor but locally very important legume species (e.g., pigeonpea, lentil, faba bean, etc.). It is anticipated that reduced cost of sequencing technologies will change the situation soon in these minor legume species.

As large amounts of genome and transcript sequence data are avaílable for many legume crops-amounts expected to expand several-fold in coming years due to heavy use of next-generation sequencing technologies-analysis, and use of genomic information for applied aspects is going to be challenging. It is anticipated that genomic information will enhance understanding of biological mechanisms, leading to new or improved screening methods for selecting superior genotypes more efficiently, and will improve the decision-making process for more efficient breeding strategies. Adoption of genomic information or markers associated with trait by the breeding community is another area that needs to be strengthened in the legume community. 


\section{ACKNOWLEDGMENTS}

Authors thank the Generation Challenge Program, National Science Foundation (DBI 0501877 and 0227414 to SAJ), Pigeonpea Genomics Initiative of Indian Council of Agricultural Research under the umbrella of Indo-US Agricultural Knowledge Initiative, and the National Fund of Indian Council for Agricultural Research (ICAR) and the Department of Biotechnology, Government of India, for funding legume research in our labs.

\section{LITERATURE CITED}

Abbo, S., C. Molina, R. Jungmann, M.A. Grusak, Z. Berkovitch, R. Reifen, G. Kahl, P. Winter, and $R$. Reifen. 2005. Quantitative trait loci governing carotenoid concentration and weight in seeds of chickpea (Cicer arietinum L.). Theor. Appl. Genet. 111:185-195.

Abraham, A., and K.M. Makkouk. 2002. The incidence and distribution of seed-transmitted viruses in pea and lentil seed lots in Ethiopia. Seed Sci. Technol. 30:567-574.

Adam-Blondon, A.F., M. Sévignac, H. Bannerot, and M. Dron. 1994. SCAR, RAPD and RFLP markers linked to a dominant gene (Are) conferring resistance to anthracnose in common bean. Theor. Appl. Genet. 88:865-870.

Alzate-Marin, A.L., M.R. Costa, K.M. Arruda, E. Gonçalves de Barros, and M.A. Moreira. 2003. Characterization of the Anthracnose resistance gene present in Ouro Negro (Hondúras 35) common bean cultivar. Euphytica 133:165-169.

Asamizu, E., Y. Nakamura, S. Sato, and S. Tabata. 2004. Characteristics of the Lotus japonicus gene repertoire deduced from large-scale expressed sequence tag (EST) analysis. Plant Mol. Biol. 54:405-414.

Atibalentja, N., S. Bekal, L.L. Domier, T.L. Niblack, G.R. Noel, and K.N. Lambert. 2005. A genetic linkage map of the soybean cyst nematode Heterodera glycines. Mol. Gen. Genomics 27.3:273-281.

Atkins, C., J.S. Pate, and J.S. Barry. 1984. Effects of short-term $\mathrm{N}_{2}$ deficiency on $\mathrm{N}$ metabolism in legume nodules. Plant Physiol. 76:705-710.

Avila, C.M., Z. Satovic, J.C. Sillero, D. Rubiales, M.T: Moreno, and A.M. Torres. 2004. Isolate and organ-specific QTLs for Ascochyta blight resistance in faba bean (Vicia faba L.). Theor. Appl. Genet. 108:1071-1078.

Azhaguvel, P., S.D. Vidya, A. Sharma, and R.K. Varshney. 2006. Methodological advancement in molecular markers to delimit the gene(s) for crop improvement. pp. 460-499. In: da Silva J. Teixera (ed.), Floriculture, ornamental and plant biotechnology: Advances and topical issues. Global Science Books, London, UK.

Beckmann, C.H. 1987. The nature of wilt diseases of plants. APS Press, St. Paul, MN, USA. Beebe, S.E., M. Rojas-Pierce, X.L. Yan, M.W. Blair, F. Pedraza, F. Munoz, J. Tohme, and J.P. Lynch. 2006. Quantitative trait loci for root architecture traits correlated with phosphorus acquisition in common bean. Crop Sci. 46:413-423.

Beebe, S.E., M.W. Blair, E. Tovar, I. Rao, M.A. Grajales, C. Cajiao, and J.B. Cuasquer. 2005. Identification of QTL for drought tolerance in common bean. pp. 174-179. In: Annual Report, Biotechnology Research Project. CIAT, Colombia.

Benedito, V.A., I. Torres-Jerez, J.D. Murray, A. Andriankaja, S. Allen, K. Kakar, M. Wandrey, J. Verdier, H. Zuber, T. Ott, S. Moreau, A. Niebel, T. Frickey, G. Weiller, J. He, X. Dai, P.X. 
Zhao, Y. Tang, and M.K. Udvardi. 2008. Gene expression atlas of the model legume Medicago truncatula. The Plant J. 55:504-513.

Bianchi-Hall, C.M., T.E. Carter, M.A. Bailey, M.A.R. Mian, T.W. Rufty, D.A. Ashley, H.R. Boerma, C. Arellano, R.S. Hussey, and W.A. Parrott. 2000. Aluminum tolerance associated with quantitative trait loci derived from soybean PI 416937 in hydroponics. Crop Sci. 40:538-545.

Blair, M.W., G. Iriarte, and S. Beebe. 2006. QTL analysis of yield traits in an advanced backcross population derived from a cultivated Andean $\times$ wild common bean (PhaseoIus vulgaris I.) cross. Theor. Appl. Genet. 112:1149-1163.

Blair, M.W., M.C. Muñoz, and S.E. Beebe. 2002. Towards QTL analysis of drought and abiotic stress tolerance in common bean RIL populations. pp. 68-72. In: Annual report, Biotechnology Research Project. CIAT, Colombia.

Blair, M.W., F. Pedraza, H.F. Buendía, E. Gaitán-Solís, S.E. Beebe, P. Gepts, and J. Tohme. 2003. Development of a genome-wide anchored microsatellite map for common bean (Phaseolus vulgaris L.). Theor. Appl. Genet. 107:1362--1374.

Blair, M.W., L.M. Rodriguez, F. Pedraza, F. Morales, and S. Beebe. 2007. Genetic mapping of the bean golden yellow mosaic geminivirus resistance gene bgm-1 and linkage with potyvirus resistance in common bean (Phaseolus vulgaris L.). Theor. Appl. Genet. 114:261-271.

Boukar, O., L. Kong, B.B. Singh, L. Murdock, and H.W. Ohm. 2004. AFLP and AFLPderived SCAR markers associated with Striga gesnerioides resistance in cowpea. Crop Sci. 44:1259-1264.

Burow, M.D., C.E. Simpson, J.L. Starr, and A.H. Paterson. 2001. Transmission genetics of chromatin from a synthetic amphiploid in cultivated peanut (A. hypogaea L.): Broadening the gene pool of a monophyletic polyploid species. Genetics 159:823-837.

Cahill, D.J., and D.H. Schmidt. 2004. Use of marker assisted selection in a product development breeding program: New directions for a diverse planet. In: Proceedings of the 4th International Crop Science Congress, Sept. 26-Oct 1, 2004, Brisbane, Australia.

Cannon, S.B., L. Sterck, S. Rombauts, S. Sato, X. Wang, J.Mudge, J. Vasdewani, F. Cheung, J.P. Gouzy, T. Schiex, M. Spanngl, H. Schoof, C. Nicholson, S. Humphays, K. Mayer, J. Rogers, F. Quetier, G.E. Oldroyd, F. Debelle, D.R. Cook, C.D. Town, B.A. Roe, S. Tabata, Y. Van de. Peer, and N.D. Young. 2006. Legume genome evolution viewed through the Medicago truncatula and Lotus japonicus genomes. Proc. Natl. Acad. Sci. (USA) 103:14959-14964.

Carmona, M.A., M.E. Gally, and S.E. Lopez. 2005. Asian soybean rust: Incidence, severity, and morphological characterization of Phakopsora pachyrhizi (uredinia and telia) in Argentina. Plant Dis. 89:109-109.

Checa, O.E., and M.W. Blair. 2008. Mapping QTL for climbing ability and component traits in common bean (Phaseolus vulgaris L.). Mol. Breed. 22:201-215.

Chen, Q.-S, Z.C. Zhang, C.-Y. Liu, D.-W. Xin, H.-M. Qui, D.-P. Shan, C.-Y. Shan, and G.-H. Hu. 2007. QTL Analysis of major agronomic traits in soybean. Agri. Sci. China 6:399-405.

Cho, S., W. Chen, and F.J. Muehlbauer. 2004. Pathotype specific genetic factors in chickpea (Cicer arietinum L.) for quantitative resistance to Ascochyta blight. Theor. Appl. Genet. 109:733-739.

Cho, S., J. Kumar, J.L. Schultz, K. Anupama, F. Tefera, and F.J. Muehlbauer. 2002. Mapping genes for double podding and other morphological traits in chickpea. Euphytica 128:285-292.

Choi, H.K., J.H. Mun, D.J. Kim, H. Zhu, J.M. Baek, J. Mudge, B. Roe, N. Ellis, J. Doyle, and G. B. Kiss. 2004. Estimating genome conservation between crop and model legume species. Proc. Natl. Acad. Sci. (ỤSA) 101:15289-15294. 
Chung, J., H.L. Babka, G.L. Graef, P.E. Staswick, D.J. Lee, P.B. Cregan, R.C. Shoemaker, and J. E. Specht. 2003. The seed protein, oil, and yield QTL on soybean linkage group I. Crop Sci. 43:1053-1067.

Cobos, M., J. Rubio, R. Strange, M.J. Moreno, Gil, and T. Millan. 2006. A new QTL for Ascochyta blight resistance in an RIL population derived from an interspecific cross in chickpea. Euphytica 149:105-111.

Cobos, M.J., M.J. Fernández, J. Rubio, M. Kharrat, M.T. Moreno, J. Gil, and T. Millán. 2005. A linkage map of chickpea (Cicer arietinum L.) based on populations from Kabuli $\times$ Desi crosses: Location of a resistance gene for Fusarium wilt race 0. Theor. Appl. Genet. 110:1347-1353.

Collard, B.C.Y., E.C.K. Pang; P.K. Ades, and P.W.J. Taylor. 2003. Preliminary investigation of QTLs associated with seedling resistance to Ascochyta blight from Cicer echinospermum, a wild relative of chickpea. Theor. Appl. Genet. 107:719-729.

Combier, P.J., T. Vernie, S. Moreau, T. Ott, L. Godiard, A. Niebel, and P. Gamas. 2008. Novel symbiotic regulatory genes identified by transcriptomics in. Medicago truncatula. pp. 42221-4222. In: F.D. Dakora, S.B.M. Chimphango, A.J. Valentine, C. Elmerich, and W.E. Newton (eds.), Current plant science and biotechnology in agriculture biological nitrogen fixation: Towards poverty alleviation through sustainable agriculture. Springer, The Netherlands.

Concibido, V.C., B.W. Diers, and P.R. Arelli. 2004. A decade of QTL mapping for cyst nematode resistance in soybean. Crop Sci. 44:1121-1131.

Consortium, D.G.. 2007. Evolution of genes and genomes on the Drosophila phylogeny. Nature 450:203-218.

Cook, D.R.. 1999. Medicago truncatula-a model in the making! Curr. Opin. Plant Biol. 2:301-304.

Coram, T.E., N. Mantri, R. Ford, and E.C.K. Pang. 2007. Functional genomics in chickpea: an emerging frontier for molecular-assisted breeding. Funct. Plant Biol. 34:861-873.

Coram, T.E., and E.C.K. Pang. 2005a. Isolation and analysis of candidate ascochyta blight defence genes in chickpea. Part I. Generation and analysis of an expressed sequence tag (EST) library. Physiol. Mol. Plant. Path. 66:192-200.

Coram, T.E., and E.C.K. Pang. 2005b. Isolation and analysis of candidate ascochyta blight defense genes in chickpea. Part II. Microarray expression analysis of putative defencerelated ESTs. Physiol. Mol. Plant Path. 66:201-210.

Coram, T.E., and E.C.K. Pang. 2006. Expression profiling of chickpea genes differentially regulated during a resistance response to Ascochyta rabiei. J. Plant Biotech. 4:647-666.

Coyne, D.P., J.R. Steadman, G. Godoy-Lutz, R. Gilbertson, E. Arnaud-Santana, J.S. Beaver, and J.R. Myers. 2003. Contributions of the bean/cowpea CRSP to management of bean diseases. Field Crop Res. 82:155-168.

Cregan, P.B., T. Jarvik, A.L. Bush, R.C. Shoemaker, K.G. Lark, A.L. Kahler,.N. Kaya, T.T. van Toai, D.G. Lohnes, J. Chung, and J.E. Specht. 1999. An integrated genetic linkage map of the soybean genome. Crop Sci. 39:1464-1490.

Croser, J.S., H.J. Clarke, K.H.M. Siddique, and T.N. Khan. 2003. Low temperature stress: implications for chickpea (Cicer arietinum L.) improvement. Critical Rev. Plant Sci. 22:185-219.

Csanádi, G., J. Vollmann, G. Stift, and T. Lelley. 2001. Seed quality QTLs identified in a molecular map of early maturing soybean. Theor. Appl. Genet. 103:912-919.

Das, S., P.R. Bhat, C. Sudhakar, J.D. Ehlers, S. Wanamaker, P.A. Roberts, X. Cui, and T. J. Close. 2008. Detection and validation of single feature polymorphisms in cowpea (Vigna unguiculata L. Walp) using a soybean genome array. BMC Genomics 9:107. 
de Arruda, M.C. A.L. Alzate-Marin, J.M. Chagas, M.A. Moreira, and E.G. de Barros. 2000. Identification of random amplified polymorphic DNA markers linked to the co-4 resistance gene to Colletotrichum lindemuthianum in common bean. Phytopath. 90:758-761.

Dirlewanger, E., P.G. Isaac, S. Ranade, M. Belajouza, R. Cousing, and D. de Vienne. 1994. Restriction fragment length polymorphism analysis of loci associated with disease resistance gene and developmental traits in Pisum sativum L. Theor. Appl. Genet. 88:17-27.

Dita, M.A., N. Rispail; E. Prats, D. Rubiales, and K.B. Singh. 2006. Biotechnology approaches to overcome biotic and abiotic stress constraints in legumes. Euphytica 147:1-24.

Doyle, J.J., J.A. Chappill, D.C. Bailey, and T. Kajita. 2000. Towards a comprehensive phylogeny of legumes: evidence from rbcL sequences and non-molecular data. pp. 1-20. In: P.S. Herendeen and A. Bruneau (eds.), Advances in legume systematics. Royal Botanical Gardens, Kew.

Du-Preez, E.D., N.C. van Rij, K.F. Lawrence, M.R. Miles, and:R.D. Frederick. 2005. First report of soybean rust (Phakopsora pachyrhizi) on dry beans in South Africa. Plant Dis. 89:206.

Duran, Y., R. Fratini, P. Garcia, and M. Perez de la Vega. 2004. An inter subspecific genetic map of lens. Theor. Appl. Genet. 108:1265-1273.

Duranti, M., and C. Gius. 1997. Legume seeds: protein content and nutritional value. Field Crops Res. 53:31-45.

Dwivedi, S.L., J.H. Crouch, S.N. Nigam, M.E. Ferguson, and A.H. Paterson. 2003. Molecular breeding of groundnut for enhanced productivity and food security in the semi-arid tropics: Opportunities and challenges. Adv. Agron. 80:153-221.

Dwivedi, S.L., M.W. Blair, H.D. Upadhyaya, R. Serraj, J. Balaji, H.K. Buhariwalla, R. Ortiz, and J.H. Crouch. 2006. Using genomics to exploit grain legume biodiversity in crop improvement. Plant Breed. Rev. 26:171-357.

Dwivedi, S.L., H.D. Upadhyaya, H.T. Stalker, M.W. Blair, D. Bertioli, S. Nielen, and R. Ortiz. 2007. Enhancing crop gene pools of cereals and legumes with beneficial traits using wild relatives. Plant Breed Rev. 30:179-230.

Ellis, T.H.N., L. Turner, R.P. Hellens, D. Lee, C.L. Harker, C. Enard, C. Domoney, and D:R. Davies. 1992. Linkage map in pea. Genetics 130:649-663.

Ellwood, S.R., H.T.T. Phan, M. Jordan, J. Hane, A.M. Torres, C.M. Avila, S. Cruz-Izquierdo, and R.P. Oliver. 2008. Construction of a comparative genetic map in faba bean (Vicia faba L.); conservation of genome structure with Lens culinaris. BMC Genomics 9:380.

Eujayl, I., M. Baum, W. Powell, W. Erskine, and E. Pehu. 1998a. A genetic linkage map of lentil (Lens sp.) based on RAPD and AFLP markers using recombinant inbred lines. Theor. Appl. Genet. 97:83-89.

Eujayl; I., W. Erskine, M. Baum, and E. Pehu. 1999. Inheritance and linkage analysis of frost injury in lentil. Crop Sci. 39:639-642.

Eujayl, I., W. Erskine, B. Bayaa, M. Baum, and E. Pehu. 1998b. Fusarium vascular wilt in lentil: inheritance and identification of DNA markers for resistance. Plant Breed. 117:497-499.

Ewa, U.B., M. Hodeba, and T. George. 2000. Construction of a genetic linkage map and QTL analysis using a recombinant inbred population derived from an interspecific cross of cowpea [Vigna unguiculata (L.) Walp.]. Breeding Sci. 50:161-172.

Fatokun, C.A., D.I. Menancio-Hautea, D. Danesh, and N.D. Young. 1992. Evidence for orthologous seed weight genes in cowpea and mung bean based on RFLP mapping. Genetics 132:841-846. 
Ferdous, S.A., S. Watanabe, C. Suzuki-Orihara, Y. Tanaka, M. Kamiya, N. Yamanaka, and K. Harada. 2006. QTL analysis of resistance to soybean cyst nematode race 3 in soybean cultivar Toyomusume. Breed. Sci. 56:155-163.

Flandez-Galvez, H., P.K. Ades, R. Ford, E.C.K. Pang, and P.W.J. Taylor. 2003a. QTL analysis for Ascochyta blight resistance in an intraspecific population of chickpea (Cicer arietinum L.). Theor. Appl. Genet. 107:1257-1265.

Flandez-Galvez, H., R. Ford, E.C. Pang, and P.W.J. Taylor. 2003b. An intraspecific linkage map of the chickpea (Cicer arietinum L.) genome based on sequence tagged microsatellite site and resistance gene analog markers. Theor. Appl. Genet. 106:1447-1456.

Fondevilla, S., Z. Satovic, D. Rubiales, M.T. Moreno, and A.M. Torres. 2008. Mapping of quantitative trait loci for resistance to Mycosphaerella pinodes in Pisum sativum subsp. syriacum. Mol. Breed. 21:439-454.

Fondevilla, S., A.M. Torres, M.T. Moreno, and D. Rubiales. 2007. Identification of a new gene for resistance to powdery mildew in Pisum fulvum, a wild relative of pea. Breeding Sci. Vol. 57:181-184.

Foster-Hartnett, D., A. Cooper, D. Danesh, D. Larsen, T. Schmidt, R. Staggs, J.A. Crow, E. Retzel, N.D. Young, R.C. Shoemaker, L.F. Marek, J. Mudge, L. Darnielle, D. Grant, N. Hanson, M. Paz, Y. Huihuang, R. Denny, and K. Larson. 2001. Soybean genomic survey: BAC-end sequences near RFLP and SSR markers. Genome 44:572-581.

Fratini, R., Y. Durán, P. García, and M. Pérez de la Vega. 2007. Identification of quantitative trait loci (QTL) for plant structure, growth habit and yield in lentil. Spanish J. Agril. Res. 5:348-356.

Frei, A., M.W. Blair, C. Cardona, S.E. Beebe, H. Gu, and S. Dorn. 2005. QTL mapping of resistance to Thrips palmikarny in common bean. Crop. Sci. 45:379-387.

Freyre, R., P.W. Skroch, V. Geffroy, A.F. Adam-Blondon, A. Shirmohamadali, W.C. Johnson, V. Llaca, R.O. Nodari, P.A. Pereira, S.M. Tsai, J. Tohme, M. Dron, J. Niehuis, C.E. Vallejos, and P. Gepts. 1998. Towards an integrated linkage map of common bean. 4. Development of a core linkage map and alignment of RFLP map. Theor. Appl. Genet. 97:847-856.

Funatsuki, H., K. Kawaguchi, S. Matsuba, Y. Sato, and M. Ishimoto. 2005. Mapping of QTL associated with chilling tolerance during reproductive growth in soybean. Theor. Appl. Genet. 111:851-861.

Gao, Z., S. Eyers, C. Thomas, N. Ellis, and A. Maule. 2004. Identification of markers tightly linked to sbm recessive genes for resistance to pea seed-borne mosaic virus. Theor. Appl. Genet. 109:488-494.

Garcia, A., E.S. Calvo, R.A. de Souza Kithl, A. Harada, D.M. Hiromoto, and L.G. Vieira. 2008. Molecular mapping of soybean rust (Phakopsora pachyrhizi) resistance genes: discovery of a novel locus and alleles. Theor. Appl. Genet. 117:545-53.

Garcia, G.M., H.T. Stalker, and G. Kochert. 1995. Introgression analysis of an interspecific hybrid population in peanuts (Arachis hypogaea L.) using RFLP and RAPD markers. Genome 38:166-176.

Garzón, L.N., G.A. Ligarreto, and M.W. Blair. 2008. Molecular marker-assisted backcrossing of anthracnose resistance into Andean climbing beans (Phaseolus vulgaris L.). Crop Sci. 48:562-570.

Gaur, P.M., and A.E. Slinkard. 1990a. Genetic control and linkage relations of additional isozymes markers in chickpea. Theor. Appl. Genet. 80:648-653.

Gaur, P.M., and A.E. Slinkard. 1990b. Inheritance and linkage of isozyme coding genes in chickpea. J. Hered. 81:455-461.

Geffroy,'V., F. Creusot, J. Falquet, M: Sévignac, A.F. Adam-Blondon, H. Bannerot, P. Gepts; and M. Dron. 1998. A family of LRR sequences in the vicinity of the Co-2 locus for 
anthracnose resistance in Phaseolus vulgaris and its potential use in marker-assisted selection. Theor. Appl. Genet. 96:494-502.

Gepts, P., F.J.L. Aragão, E. de Barros, M.W. Blair, O. Brondani, W. Broughton, I. Galasso, G. Hernández, J. Kami, P. Lariguet, P. McClean, M. Melotto, P. Miklas, P. Pauls, A. PedrosaHarand, T. Porch, F. Sánchez, F. Sparvoli, and K. Yu. 2008. Genomics of Phaseolus beans, a major source of dietary protein and micronutrients in the tropics. pp. 113-143. In: P.H. Moore and R. Ming (eds.), Plant genetics and genomics: Crops and models. Vol. 1. Springer, New York.

Gilpin, B.J., J.A. McCallum, T.J. Frew, and G.M. Timmerman-Vaughan. 1997. A linkage map of the pea (Pisum sativum L.) genome containing cloned sequences of known function and expressed sequence tags (ESTs). Theor. Appl. Genet. 95:1289-1299.

Githiri, S.M., D. Yang, N.A. Khan, D. Xu, T. Komatsuda, and R. Takahashi. 2007. QTL analysis of low temperature induced browning in soybean seed coats. J. Hered. 98:360-366.

Gobbi, A., C. Teixeira, M. Moretzsohn, P. Guimaraes, S. Leal-Bertioli, D. Bertioli, C.R. Lopes, and M. Gimenes. 2006. Development of a linkage map to species of B genome related to the peanut (Arachis hypogaea-AABB). P 679. Plant and Animal Genome XIV Conference, Jan 14-18'2006, San Diego, CA, USA. (http://www.intlpag.org/14/abstracts/ PAG14_P679.htmi).

Grisi, M.C.M., M.W. Blair, P. Geptes, C. Borandani, P.A.A. Pereira, and R.P.V. Brondani. 2007. Genetic mapping of a new set of microsatellite markers in a reference common bean population BAT93 $\times$ Jalo EEP558. Genet. Mol. Res. 6:691-706.

Grusak, M.A. 2002. Enhancing mineral content in plànt food products. J. Am. College Nutr. 21:178S-183S.

Guo, B., D.A. Sleper, P.R. Arelli, J.G. Shannon, and H.T. Nguyen. 2005. Identification of QTLs associated with resistance to soybean cyst nematode races 2,3 and 5 in soybean PI 90763. Theor. Appl. Genet. 111:965-971.

Guo, B., D.A. Sleper, P. Lu, J.G. Shannon, H.T. Nguyen, and P.R. Árelli. 2006a. QTLs associated with resistance to soybean cyst nematode in soybean: meta-analysis of QTL locations. Crop Sci. 46:595-602.

Guo, B., D.A. Sleper, H. Nguyen, P.R. Arelli, and G. Shannon. 2006b. QTL mapping of resistance to soybean cyst nematode races 1, 2, and 5 in soybean PI 404198A. Crop Scci. 46:224-233.

Guo, X., D. Wang, S.G. Gordon, E. Helliwell, T. Smith, S.A. Berry, and S.K.St. Martin, A.E.. 2008. Dorrance Genetic Mapping of QTLs Underlying Partial Resistance to Sclerotinia sclerotiorum in Soybean PI 391589A and PI 391589B. Crop Sci. 48:1129-1139.

Gupta, P.K. 2008. Single-molecule DNA sequencing technologies for future genomićs research. Trends Biotech. 26:602-611.

Gupta, P.K., and R.K. Varshney. 2000. The development and use of microsatellite markers for genetics and plant breeding with emphasis on bread wheat. Euphytica. 113:163-185.

Gupta, P.K., and R.K. Varshney. 2004. Cereal Genomics. KIuwer Academic Publishers, Dordrecht, The Netherlands.

Guzman-MaIdonado, S.H., O. Martinez, J.A. Acosta-Gallegos, F. Guevara-Lara, and O. Paredes-Lopez. 2003. Putative quantitative trait loci for physical and chemical components of common bean. Crop Sci. 43:1029-1035.

Halward, T.M., H.T. Stalker, and G. Kochert. 1993. Development of an RFLP linkage map in diploid peanut species. Theor. Appl. Genet. 87:379-384.

Harnwieh, A., S.M. Udupa, W. Choumane, A. Sarker, F. Dreyer, C. Jung, and M. Baum. 2005. A genetic linkage map of Lens $s p$. based on microsatellite and AFLP markers and the localization of fusarium vascular wilt resistance. Theor. Appl. Genet. 110:669-677. 
Han, Y., W. Teng, K. Yu, V. Poysa, T. Anderson, L. Qiu, D.A. Lightfoot, and W. Li. 2007. Mapping QTL tolerance to Phytophthora root rot in soybean using microsatellite and RAPD/SCAR derived markers. Euphytica 162:231-239.

Handberg, J., and J. Stougaard. 1992. Lotus japonicus, an autogamous, diploid legume species for classical and molecular genetics. Plant J. 2:487-496.

Havey, M.J., and F.J. Muehlbauer. 1989. Linkages between restriction fragment length, isozyme, and morphological markers in lentils. Theor. Appl. Genet. 77:395-401.

Herselman, L., R. Thwaites, F.M. Kimmins, B. Courtois, R.J.A. van der Merwe, and S.E. Seal. 2004. Identification and mapping of AFLP markers linked to peanut (Arachis hypogaea L.) resistance to the aphid vector of groundnut rosette disease. Theor. Appl. Genet. 109:1426-1433.

Hong, L., X. Yan, G. Rubio, S.E. Beebe, M.W. Blair, and J.P. Lynch. 2004. Genetic mapping of basal root gravitropism and phosphorus acquisition efficiency in common bean. Funct. Plant Biol. 31:959-970.

Hudson, M.. 2008. Sequencing breakthroughs for genomic ecology and evolutionary biology. Mol. Ecol. Res. 8:3-17.

Hyten, D., V. Pantalone, C. Sams, A. Saxton, D. Landau-Ellis, T. Stefaniak, and M. Schmidt. 2004. Seed quality QTL in a prominent soybean population. Theor. Appl. Genet. 109:552-561.

Hyten, D.L., Q. Song, I. Choi, M. Yoon, J.E. Specht, L.K. Matukumalli, R.L. Nelson, R.C. Shoemaker, N.D. Young, and P.B. Cregan. 2008. High-throughput genotyping with the GoldenGate assay in the complex genome of soybean. Theor. Appl. Genet. 116:945-52.

Irsigler, A.S.T., M.D.L. Costa, P. Zhang, P.A.B. Reis, R.E. Dewey, R.S. Boston, and E.P.B. Fontes. 2007. Expression profiling on soybean leaves reveals integration of ER- and osmotic-stress pathways. BMC Genomics 8:431.

Irzykowska, L., and B. Wolko. 2004. Interval mapping of QTLs controlling yield-related traits and seed protein content in Pisum sativum. J. Appl. Genet. 45:297-306.

Irzykowska, L., B. Wolko, and W.K. Swiecicki. 2001. The genetic linkage map of pea (Pisum sativum L.] based on molecular marker, biochemical, and morphological markers. Pisum Genet. 33:13-18.

Jackson, S.A., D. Rokhsar, G. Stacey, R.C. Shoemaker, J. Schmutz, and J. Grimwood. 2006. Toward a reference sequence of the soybean genome: A multiagency effort. Crop Sci. 46: S-55-S-61.

Janila, P., and B. Sharma. 2004. RAPD and SCAR markers for powdery mildew resistance gene in pea. Plant Breed. 123:271-274.

Johnson, W.C., P. Guzman, D. Mandala, A.B.C. Mkandawire, S. Temple, R.L. Gilbertson, and P. Gepts. 1997. Molecular tagging of the bc-3 gene for introgression into Andean common bean. Crop sci. 37:248-254.

Jones, N., H. Ougham, and $H$. Thomas. 1997. Markers and mapping: we are all geneticists now. New Phytol. 137:165-177.

Jun, T.H., K. Van; M.Y. Kim, S.H. Lee, and D.R. Walker. 2008. Association analysis using SSR markers to find QTL for seed protein content in soybean. Euphytica 162:179-191.

Jung, G., D.P. Coyne, P.W. Skroch, J. Nienhuis, E. Arnaud-Santana, J. Bokosi, H.M. Ariyarathne, J.R. Steadman, J.S. Beaver, and S.M. Kaeppler. 1996. Molecular markers associated with plant architecture and resistance to common blight, web blight, and rust in common beans. J. Am. Soc. Hort. Sci. 121:794-803.

Jung, G., H.M. Ariyarathne, D.P. Coyne, and J. Nienhuis. 2003. Mapping QTL for bacterial brown spot resistance under natural infection in field and seeding stem inoculation in growth chamber in common bean. Crop Sci. 43:350-357. 
Kahraman, A., I. Kusmenoglu, N. Aydin, A. Aydogan, W. Erskine, and F.J. Muehlbauer. 2004. QIL mapping of winter hardiness genes in lentil. Crop Sci. 44:13-22.

Kashiwagi, J., L. Krishnamurthy, J.H. Crouch, and R. Serraj. 2006. Variability of root length density and its contributions to seed yield in chickpea (Cicer arietinum L.) under terminal drought stress. Field Crops Res. 95:171-181.

Kashiwagi, J., L. Krishnamurthy, R. Serraj, H.D. Upadhyaya, S.H. Krishna, S. Chandra, and V: Vadez. 2005. Genetic variability of drought-avoidance root traits in the mini-core germplasm collection of chickpea (Cicer arietinum L.). Euphytica 146:213-222.

Kassem, M.A., K. Meksem, C.H. Kang, V.N. Njiti, V. Kilo, A.J. Wood, and D.A. Lightfoot. 2004. Loci underlying resistance to manganese toxicity mapped in a soybean recombinant inbred line population of Essex $\times$ Forrest. Plant and Soil 260:197-204.

Kassem, M.A., J. Shultz, K. Meksem, Y. Cho, A.J. Wood, M.J. Iqual, and D.A. Lightfoot. 2006. An updated Essex $\times$ Forrest linkage map and first composite interval map of QTL underlying six soybean traits. Theor. Appl. Genet. 113:1115-1126.

Kazan, K.; F.J. Muehlbauer, N.E. Weeden, and G. Ladizinsky. 1993. Inheritance and linkage relationships of morphological and isozyme loci in chickpea (Cicer arietinum L.). Theor. Appl. Genet. 86:417-426.

Kazi, S., J. Shultz, J. Afzal,J. Johnson, V.N. Njiti, and D.A. Lightfoot. 2008. Separate loci underlie resistance to root infection and leaf scorch during soybean sudden death syndrome. Theor. Appl. Genet. 116:967-977.

Keim; P., B.W. Diers, T.C. Olson, and R.C. Shoemaker. 1990. RFLP Mapping in soybean: Association between marker loci and variation in quantitative traits. Genetics 126:735-742.

Keim, P., J.M. Schupp, S.E. Travis, K. Clayton, T. Zhu, L. Shi, A. Ferreira, and D.M. Webb. 1997. A high-density soybean genetic map based on AFLP markers. Crop Sci. 37:537-543.

Khan, N.A., S.M. Githiri, E.R. Benitez, J. Abe, S. Kawasaki, T. Hayashi, and R. Takahashi. 2008. QTL analysis of cleistogamy in soybean. Theor. Appl. Genet. 117:479-87.

Khedikar, Y., K.V. Patgar, M.V.G. Gowda, H.D. Upadhyaya, and R.K. Varshney. 2009. Linkage mapping and QTL analysis for rust and late leaf spot in groundnut (Arachis hypogaea L.) P 357. Plant \& Animal Genome 17th Conference, Jan. 10-14, 2009. San Diego, CA (www.intl-pag.org/17/abstracts/P05f_PAGXVII_357.html).

Killian, A., E. Huttner, P. Wenzl, D. Jaccoud, J. Carling, V. Caig, M. Evers, K. HellerUsżynska, G. Uszynski, C. Cayla, S. Patarapuwadol, L. Xia, S. Yang; and B. Thomson: 2005. The fast and the cheap: SNP and DArT-based whole genome profiling for crop improvement. pp. 443-461. In: In the wake of double helix: from the green revolution to the gene revolution. Proceedings of the International Congress, May 27-31, 2003, Bologna, Italy.

Kim, M.S., M.J. Park, W.H. Jeong, K.C. Nam, and J.I. Chung. 2006. SSR marker tightly linked to the Ti locus in soybean [Glycine max (L.) Merr.]. Euphytica 152:361-366.

Koebner, R.M.D., and S. Richard. 2002. The impact of molecular markers on the wheat breeding paradigm. Cell. Mol. Bio. Lett. 7:695-702.

Kolkman, J.M., and J.D. Kelly. 2003. QTL conferring resistance and avoidance to white mold in common bean. Crop Sci. 43:539-548.

Kotresh, H., B. Fakrudin, S. Punnuri, B. Rajkumar, M. Thudi, H. Paramesh, H. Lohithswa, and M. Kuruvinashetti. 2006. Identification of two RAPD markers genetically inked to a recessive allele of a Fusarium wilt resistance gene in pigeonpea [Cajanus cajan (L.) Millsp.]. Euphytica 149:113-120.

Kottapalli, P., P.M. Gaur, S.K. Katiyar, J.H. Crouch, H.K. Buhariwalla, S. Pande, and K.K. Gali. 2009. Mapping and validation of QTLs for resistance to an Indian isolate of ascochyta blight pathogen in chickpea. Euphytica 165:79-88. 
Krishnamurthy, L., V. Vadez, M. Jyotsna Devi, R. Serraj, S.N. Nigam, M.S. Sheshshayee, S. Chandra, and R. Aruna. 2007. Variation in transpiration efficiency and its related traits in a groundnut (Arachis hypogaea L.) mapping population. Field Crops Res. 103:189-197.

Kulikova, O., G. Gualtieri, R. Geurts, D.J. Kim, D.R. Cook, T. Huguet, and J.H. de Jong. 2001. Integration of the FISH pachytene and genetic maps of Medicago truncatula. Plant J. 27:49-58.

Kulkarni, N.K., P.L. Kumar, V. Muniyappa, A.T. Jones, and D.V.R. Reddy. 2002. Transmission of pigeon pea sterility mosaic virus by the eriophyid mite, Aceria cajani (Acari: Arthropoda). Plant Dis. 86:1297-1302.

Kumutha, D., R.K. Sairam, K. Ezhilmathi, V. Chinnusamy, and R.C. Meena. 2008. Effect of waterlogging on carbohydrate metabolism in pigeonpea (Cajanus cajan L.): Up-regulation of sucrose synthase and alcohol dehydrogenase. Plant Sci. 175:706-716.

Laucou, V., K. Haurogne, N. Ellis, and C. Rameau. 1998. Genetic mapping in pea. 1. RAPDbased genetic linkage map of Pisum sativum. Theor. Appl. Genet. 97:905-915.

Leal-Bertioli S.C.M., A.C.V.F. Jose, D.M.T. Alves-Freitas, M.C. Moretzsohn, P.M. Guimaraes, S. Nielen, B.S. Vidigal, R.W. Pereira, J. Pike, A.P. Favero, M. Parniske, R.K. Varshney, and D.J. Bertioli. 2009 Identification of candidate genome regions controlling disease resistance in Arachis. BMC Plant Biol. 9:112.

Lee; G.J., H.R. Boerma, M.R. Villagarcia, X. Zhou, T.E. CarterJr., Z. Li, and M.O. Gibbs. 2004. A major QTL conditioning salt tolerance in S-100 soybean and descendent cultivars. Theor. Appl. Genet. 109:1610-1619.

Lee, S.H., K.Y. Park, H.S. Lee, E.H. Park, and H.R. Boerma. 2001. Genetic mapping of QTL conditioning soybean sprout yield and quality. Theor. Appl. Genet. 103:702-709.

Lee, S.H., M.A. Bailey, M.A.R. Mian, T.E. Carter Jr., E.R. Shipe, D.A. Ashley, W.A. Parrott, R.S. Hussey, and H.R. Boerma. 1996. RFLP loci associated with soybean seed protein and oil content across populations and locations. Theor. Appl. Genet. 93:649-657.

Lewers, K.S., E.H. Crane, C.R. Bronson, J.M. Schupp, P. Keim, and R.C. Shoemaker. 1999. Detection of linked QTL, for soybean brown stem rot resistance in 'BSR 101' as expressed in a growth chamber environment. Mol. Breed. 5:33-42.

Li, W., D. Sun, Y. Du, Q. Chen, Z. Zhang, L. Qiu, and G. Sun. 2007. Quantitative trait loci uriderlying the development of seed composition in soybean [Glycine max (L.) Merr.]. Genome 50:1067-1077.

Li, Y.D., Y.J. Wang, Y.P. Tong, J.G. Gao, J.S. Zhang, and S.Y. Chen. 2005. QTL mapping of phosphorus deficiency tolerance in soybean [Glycine max (I.) Merr.]. Euphytica 142:137-142.

Lichtenzveig, J., D.J. Bonfil, H.B. Zhang, D. Shtienberg, and S. Abbo. 2006. Mapping quantitative trait loci affecting time to flowering and response to Ascochyta blight in chickpea. Theor. Appl. Genet. 113:1357-1369.

Lin, S.F., D. Grant, S. Cianzio, and R.C. Shoemaker. 2000. Molecular characterization of iron deficiency chlorosis in soybean. J. Plant Nutr. 23:1929-1939.

Link, W., C.Balko, and F.L. Stoddard. 2008. Winter hardiness in faba bean: physiology and breeding. Field Crops Res. doi: 10.1016/j.fcr.2008.08.004.

Linkemer, G., J.E. Board, and M.E. Musgrave. 1998. Waterlogging effect on growth and yield components of late-planted soybean. Crop Sci. 38:1576-1584.

Liu, B., T. Fujita, Z.H. Yan, S. Sakamoto, D. Xu, and J. Abe. 2007. QTL mapping of domestication-related traits in soybean (Glycine max). Ann. Bot. 100:1027-1038.

Liu, S., K. Yu,1 and S.J. Park. 2008. Development of STS markers and QTL validation for common bacterial blight resistance in common bean. Plant Breed. 127:62-68.

Lodwig, E., and P. Poole. 2003. Metabolism of Rhizobium bacteroids. Crit. Rev. Plant Sci. $22: 37-78$. 
Loridon, K., K. McPhee, J. Morin, P. Dubreuil, M.L. Pilet-Nayel, G. Aubert, C. Rameau, A. Baranger, C. Coyne, I. Lejeune-Hènaut, and J. Burstin. 2005. Microsatellite marker polymorphism and mapping in pea (Pisum sativum L.). Theor. Appl. Genet. 111:1022-1031.

Mahalakshmi, V., P. Aparna, S. Ramadevi, and R. Ortiz. 2002. Genomic sequence derived simple sequence repeats markers: A case study with Medicago spp. www.ejbiotechnology.info/content/vol5/issue3/full/2/index.html.

Mallikarjuna, N., H.C. Sharma, and H.D. Upadhyaya. 2007. Exploitation of wild relatives of pigeonpea and chickpea for resistance to Helicoverpa armigera. www.icrisat.org/gt-ci/ ResearchBreifs/exploitation_chickpea.pdf.

Mansur, L.M., A.L. Carriquiry, and A.P.R. Arelli. 1993. Generation mean analysis of resistance to race 3 of soybean cyst nematode. Crop Sci. 33:1249-1253.

Mantri, N.L., R. Ford, T.E. Coram, and E.C.K. Pang. 2007. Transcriptional profiling of chickpea genes differentially regulated in response to high-salinity, cold and drought. BMC Genomics 8:303.

Matsumura, H., B. Liu, J. Abe, and R. Takahashi. 2008. AFLP mapping of soybean maturity gene E4. J. Hered. 99:193-197.

Meksem, K., V.N. Njiti, W.J. Banz, M.J. Iqbal, My.M. Kassem, D.L. Hyten, J. Yuang, T.A. Winters, and D.A. Lightfoot. 2001. Genomic regions that underlie soybean seed isoflavone content. J. Biomed. Biotech. 1:138-144.

Melchinger, A.E.. 1990. Use of molecular markers in breeding for oligogenic disease resistances. Plant Breed. 104:1-19.

Melotto, M., L. Afanador, and J.D. Kelly. 1996. Development of a SCAR marker linked to the I gene in common bean. Genome 39:1216-1219.

Menancio-Hautea, D., C.A. Fatokum, L. Kumar, D. Danesh, and N.D. Young. 1993. Comparative genome analysis of mungbean [Vigna radiata (L.) Wilczek] and cowpea (V. unguiculata .L.) using RFLP mapping data. Theor. Appl. Genet. 86:797-810.

Mendoza, A., F. Hernandez, S. Hernandez, D. Ruiz, M. de la Vega, G. Mora, J. Acosta, and J. Simpson. 2001. Identification of Co-1 anthracnose resistance and linked molecular markers in common bean line A193. Plant Dis. 85:252-255.

Menéndez, C.M., A.E. Hall, and P. Gepts. 1997. A genetic linkage map of cowpea (Vigna unguiculata) developed from a cross between two inbred, domesticated lines. Theor. Appl. Genet. 95:1210-1217.

Mian, M.A.R., D.A. Ashley, and H.R. Boerma. 1998. An additional QTL for water use efficiency in soybean. Crop Sci. 38:390-393.

Mian, M.A.R., M.A. Bailey, D.A. Ashley, R. Wells, T.E. Carter, W.A. Parrott, and H.R. Boerma. 1996. Molecular markers associated with water use efficiency and leaf ash in soybean. Crop Sci. 36:1252-1256.

Mienie, C.M., M.M. Liebenberg, Z.A. Pretorius, and P.N. Miklas. 2005. SCAR markers linked to the common bean rust resistance gene Ur-13. Theor. Appl. Genet. 111:972-979.

Miklas, P.N., R. Delorme, and R. Riley. 2003. Identification of QTL conditioning resistance to white mold in snap bean. J. Am. Soc. Hort. Sci. 128:564-570.

Miklas, P.N., J.D. Kelly, S.E. Beebe, and M.W. Blair. 2006a. Common bean breeding for resistance against biotic and abiotic stresses: From classical to MAS breeding. Euphytica 147:105-131.

Miklas, P.N., J. Hu, Niklaus J. Grünwáld, and K.M. Larsen. 2006b. Potential application of TRAP (Targeted Region Amplified Polymorphism) markers for mapping and tagging disease resistance traits in common bean. Crop Sci. 46:910-916.

Milla, S.R.. 2003. Relationships and utilization of Arachis germplasm in peanut improvement. Ph. D. Thesis, North Carolina State University, USA, 150 pp. 
Millan, T., J. Rubio, M. Iruela, K. Daly, J.I. Cubero, and J. Gil. 2003. Markers associated with Ascochyta blight resistance in chickpea and their potential in marker-assisted selection. Field Crops Res. 84:373-384.

Moretzsohn, M.C., L. Leoi, K. Proite, P.M. Guimara, S.C.M. Leal-Bertioli, M.A. Gimenes, W. S. Martins, J.F.M. Valls, D. Grattapaglia, and D.A.J. Bertioli. 2005. Microsatellite-based, gene-rich linkage map for the AA genome of Arachis (Fabaceae). Theor. Appl. Genet. 111:1060-1071.

Morgante, M., and F. Salamini. 2003. From plant genomics to breeding practice. Curr. Opin. Biotech. 14:214-219.

Muehlbauer, F.J., W.J. Kaiser, and C.J. Simon. 1994. Potential for wild species in cool season food legume breeding. Euphytica 73:109-114.

Mun, J.H., D.J. Kim, H.K. Choi, J. Gish, F. Debellé, J. Mudge, R. Denny, G. Endré, J. Dénarié, G.B. Kiss, B. Roe, N.D. Young, and D.R. Cook. 2006. Distribution of microsatellites in the genome of Medicago truncatula: A resource of genetic markers that integrate genetic and physical maps. Genetics 172:2541-2555.

Murray, J.D., T.E. Michaels, C. Cardona, A.W. Schaafsma, and K.P. Pauls. 2004. Quantitative trait loci for leafhopper (Empoasca fabae and Empoasca kraemeri) resistance and seed weight in the common bean. Plant Breed. 123:474-479.

Myers, G.O., C.A. Fatokun, and D.A. Young. 1996. RFLP mapping of an aphid resistance gene in cowpea (Vigna unguiculata L. Walp). Euphytica 91:181-187.

Nadimpalli, R.G., R.L. Jarret, S.C. Phatak, and G. Kochert. 1994. Phylogenetic relationships of the pigeon pea (Cajanus cajan L.) based on nuclear restriction fragment length polymorphism. Genome 36:216-223.

Naidu, R.A., F.M. Kimmins, C.M. Deom, P. Subrahmanyam, A.J. Chiyembekeza, and P.J.A. Van der Merwe. 1999. Groundnut rosette: A virus disease affecting the sustainability of groundnut production in sub-saharan Africa. Plant Dis. 83:700-709.

Nichols, D.M.; K.D. Glover, S.R. Carlson, J. Specht, and B.W. Diers. 2006. Fine mapping of a seed protein QTL on soybean linkage group I and its correlated effects on agronomic traits. Crop Sci. 46:834-839.

Nodari, R.O., S.M. Tsai, R.L. Gilbertson, and P. Gepts. 1993a. Towards an integrated linkage map of common bean. II. Development of an RFLP-based linkage map. Theor. Appl. Genet. 85:513-520.

Nodari, R.O., S.M. Tsai, P. Guzman, R.L. Gilbertson, and P. Gepts. 1993b. Towards an integrated linkage map of common bean. III. Mapping genetic factors controlling hostbacteria interactions. Genetiçs 134:341-35.

Oldeman, L.R., V.W.P. van Engelen, and J.H.M. Pulles. 1991. The extent of human-induced soil degradation. In: World Map of the Status of Human-Induced Soil Degradation: An explanatory note, pp. 27-33, L.R. Oldeman, R.T.A. Hakkeling, and W.G. Sombroek (eds.), International Soil Reference and Information Center, (ISRIC), Wageningen.

Omo-Ikerodah, E.E., I. Fawole, and C.A. Fatokun. 2008. Genetic mapping of quantitative trait loci (QTLs) with effects on resistance to flower bud thrips (Megalurothrips sjostedti) identified in recombinant inbred lines of cowpea. African J. Biotech. $7: 263-270$.

Ortiz, R.. 2003. An international public partnership for genetic enhancement of cowpea using a holistic approach to biotechnology. Genomic/Proteomic Technol. 3:45-47.

Ouédraogo, J.T., T. Jean-Baptiste, M.P. Timko, and F.J. Belzile. 2002a. AFLP markers linked to resistance against Striga gesnerioides race 1 in cowpea (Vigna unguiculata). Genome 45:787-793.

Ouédraogo, J.T., B.S. Gowda, M. Jean, T.J. Close, J.D. Ehlers, A.E. Hall, A.G. Gillaspie, P.A. Roberts, A.M. Ismail, G. Bruening, P. Gepts, M.P. Timko, and F.J. Belzile. 2002b. An 
improved genetic linkage map for cowpea (Vigna unguiculata L.) combining AFLP, RFLP, RAPD, biochemical markers, and biological resistance traits. Genome 45:175-188.

Ouédraogo, J.T., V. Maheshwari, D.K. Berner, C.-A. St-Pierre, F. Belzile, and M.P. Timko. 2001. Identification of AFLP markers linked to resistance of cowpea (Vigna unguiculata L.) to parasitism by Striga gesnerioides. Theor. AppI. Genet. 102:1029-1036.

Panthee, D.R., V.R. Pantalone, C.E. Sams, A.M. Saxton, D.R. West, J.H. Orf, and A.S. Killam. 2006. Quantitative trait loci controlling sulfur containing amino acids, methionine and cysteine, in soybean seeds. Theor. Appl. Genet. 112:546-53.

Park, S.O., D.P. Coyne, J.R. Steadman, K.M. Crosby, and M.A. Brick. 2004. RAPD and SCAR markers linked to the Ur- 6 Andean gene controlling specific rust resistance in common bean. Crop Sci. 44:1799-1807.

Pedrosa, A., N. Sandal, J. Stougaard, D. Schweizer, and A. Bachmair. 2002. Chromosomal map of the model legume Lotus japonicus. Genetics 161:1661-1672.

Pfaff, T., and G. Kahl. 2003. Mapping of gene-specific markers on the genetic map of chickpea (Cicer arietinum L.). Mol. Gen. Genomics 269:243-251.

Pilet-Nayel, M., F. Muehlbauer, R. McGee, J. Kraft, A. Baranger, and C. Coyne. 2002. Quantitative trait loci for partial resistance to Aphanomyces root rot in pea. Theor. Appl. Genet. 106:28-39.

Pivonia, S., and X:B. Yang. 2004. Assessment of the potential year round establishment of soybean rust throughout the world. Plant Dis. 88:523-529.

Primomo, V.S., V. Poysa, G.R. Ablett, C.J. Jackson, M. Gijzen, and I. Rajcan. 2005. Agronomic performance of recombinant inbred line populations segregating for isoflavone content in soybean seeds. Crop Sci. 45:2203-2211.

Prioul, S., A. Frankewitz, G. Deniot, G. Morin, and A. Baranger. 2004. Mapping of quantitative trait loci for partial resistance to Mycosphaerella pinodes in pea (Pisum sativum L.) at the seedling and adult plant stages. Theor. Appl. Genet. 108:1322-1334.

Qi, B., P. Korir, T. Zhao, D. Yu, S. Chen, and J. Gai. 2008. Mapping quantitative trait loci associated with aluminum toxin tolerance in NJRIKY recombinant inbred line population of soybean (Glycine max). J. Integr. Plant Biol. 50:1089-1095.

Radhika, P., S.J.M. Gowda, N.Y. Kadoo, L.B. Mhase, B.M. Jamadagni, M.N. Sainani, S. Chandra, and V.S. Gupta. 2007. Development of an integrated intraspecific map of chickpea (Cicer arietinum L.) using two recombinant inbred line populations. Theor. Appl. Genet. 115:209-216.

Raganin, V.A., D.A. Sanglard, T.L.P.O. de Souza, M.A. Moreira, and E.G. de Barros. 2003. Simultaneous transfer of resistance genes for rust, anthracnose, and anglular leaf spot to cultivar Perola assisted by molecular markers. Annu. Rev. Bean Improv. Coop. 46:159-160.

Rajesh, P.N., A. Tullu, J. Gil, V.S. Gupta, P.K. Ranjekar, and F.J. Muehlbauer. 2002. Identification of an STMS marker for the double-podding gene in chickpea. Theor. Appl. Genet. 105:604-607.

Rajesh, P.N., C. Coyne, K. Meksem, K.D. Sharma, V. Gupta, and F.J. Muehlbauer. 2004. Construction of a HindIII bacterial artificial chromosome library and its use in identification of clones associated with disease resistance in chickpea. Theor. Appl. Genet. 108:663-669.

Rakshit, S., P. Winter, M. Tekeoglu, J.J. Munoz, T. Pfaff, A.M. Ko-Iseppon, F.J. Muehlbauer, and G. Kahl. 2003. DAF marker tightly linked to a major locus for ascochyta blight resistance in chickpea (Cicer arietinum L.). Euphytica 132:23-30.

Ramsay, G., W. van de Ven, R. Waugh, D.W. Griffiths, and W. Powell. 1995. Mapping quantitative trait loci in faba beans. pp. 444-445. Proceedings of 2 nd European Conference on grain legumes. Copenhagen. 
Ratnaparhke, M.B., M. Tekeoglu, and F.J. Muehlbauer. 1998. Inter-simple-sequence-repeat (ISSR) polymorphisms are useful for finding markers associated with disease resistance gene cluster. Theor. Appl. Genet. 97:515-519.

Rector, B.G., J.N. All, W.A. Parrott, and H.R. Boerma. 1998. Identification of molecular markers linked to quantitative trait loci for soybean resistance to corn earworm. Theor. Appl. Genet. 96:786-790.

Reinprecht, Y., V.W. Poysa, K. Yu, I. Rajcan, G.R. Ablett, and K.P. Pauls. 2006. Seed and agronomic QTL in low linolenic acid, lipoxygenase-free soybean [Glycine max (L.) Merrill] germplasm. Genome 49:1510-1527.

Reyna, N., B. Cornelious, J.G. Shannon, and C.H. Sneller. 2003. Evaluation of a QTL for waterlogging tolerance in southern soybean germplasm. Crop Sci. 43:2077-2082.

Riggs, R.D., and T.L. Niblack. 1999. Soybean cyst nematode. pp. 52-53. In: G.L. Hartman, J.B. Sinclair, and J.C. Rupe (eds.), Compendium of soybean diseases. APS Press, St. Paul, MN.

Rodríguez-Suárez, C., B. Méndez-Vigo, A. Pañeda, J.J. Ferreira, and R. Giraldez. 2007. A genetic linkage map of Phaseolus vulgaris L. and localization of genes for specific resistance to six races of anthracnose (Colletotrichum lindemuthianum). Theor. Appl. Genet. 114:713-722.

Rodríguez-Suárez, C., J.J. Ferreira, A. Campa, A. Pañeda, and R. Giraldez. 2008. Molecular mapping and intra-cluster recombination between anthracnose race-specific resistance genes in the common bean differential cultivars Mexico 222 and Widusa. Theor. Appl. Genet. 116:807-814.

Roman, B., A.M. Torres, D. Rubiales, J.I. Cubero, and Z. Satovic. 2002. Mapping of quantitative trait loci controlling broomrape (Orobanche crenata Forsk.) resistance in faba bean (Vicia faba L.). Genome 45:1057-1063.

Roman, B., Z. Satovic, D. Pozarkova, J.Macas, J. Dolezel, J.I. Cubero, and A.M. Torres. 2004. Development of a composite map in Vicia faba, breeding applications and future prospects. Theor. Appl. Genet. 108:1079-1088.

Rubeena, T., R. Ford, and P.W.J. Taylor. 2003. Construction of an intraspecific linkage map of lentil (Lens culinaris ssp. culinaris). Theor. Appl. Genet. 107:910-916.

Rubeena, T., P.W.J. Taylor, P.K. Ades, and R. Ford. 2006. QTL mapping of resistance in lentil (Lens culinaris ssp. culinaris) to Ascochyta blight (Ascochyta lentis). Plant Breed. 12.5:506-512.

Ruben, E., A. Jamai, J. Afzal, V.N. Njiti, K. Triwitayakorn, M.J. Iqbal, S. Yaegashi, R. Bashir, S. Kazi, P. Arelli, C.D. Town, H. Ishihara, K. Meksem, and D.A. Lightfoot. 2006. Genomic analysis of the rhg1 locus: candidate genes that underlie soybean resistance to the cyst nematode. Mol. Gen. Genomics 276:503-516.

Rubiales, D., A.A. Emeran; and J.C. Sillero. 2002. Rusts on legumes in Europe and North Africa. Grain Legumes 37:8-9.

Rubio, J., E. Moussa, M. Kharrat, M.T. Moreno, T. Millán, and J. Gil. 2003. Two genes and linked RAPD markers involved in resistance to Fusarium oxysporum f. sp. ciceris race 0 in chickpea. Plant Breed. 122:188-191.

Saghai Maroof, M.A., S.C. Jeong, I. Gunduz, D.M. Tucker, G.R. Buss, and S.A. Tolin. 2008. Pyramiding of soybean mosaic virus resistance genes by marker-assisted selection. Crop Sci. 48:517-526.

Salas, P., J.C. Oyarzo-Llaipen, D. Wang, K. Chase, and L. Mansur. 2006. Genetic mapping of seed shape in three populations of recombinant inbred lines of soybean [Glycine max $L$. Merr.]. Theor. Appl. Genet. 113:1459-1466.

Saivi, S., and R. Tuberosa. 2005. To clone or not to clone plant QTLs: Present and future challenges. Trends Plant Sci. 10:297-304. 
Santra, D.K., M. Tekeoglu, and F.J. Muehlbauer. 1998. Tagging and mapping of ascochyta blight resistance genes in chickpea (Cicer arietinum L.) using recombinant inbred lines. P242 Plant \& Animal Genome 6th Conference, Jan. 18-22 1998, San Diego, CA. www.intlpag.org/6/abstracts/374.html.

Santra, D.K., M. Tekeoglu, M.L. Ratnaparkhe, W.J. Kaiser, and F.J. Muehlbauer. 2000. Identification and mapping of QTLs conferring resistance to Ascochyta blight in chickpea. Crop Sci. 40:1606-1612.

Sato, S., Y.Nakamura, T. Kaneko, E. Asamizu, T. Kato, M. Nakao, S. Sasamoto, A. Watanabe, A. Ono, K. Kawashima, T. Fujishiro, M. Katoh, M. Kohara, Y. Kishida, C. Minami, S. Nakayama, N. Nakazaki, Y. Shimizu, S. Shinpo, C. Takahashi, T. Wada, M. Yamada, N. Ohmido, M. Hayashi, K. Fukui, T. Baba, T. Nakamichi, H. Mori, and S. Tabata. 2008. Genome structure of the legume, Lotus japonicus. DNA Res. 15:227-239.

Satovic, Z., A.M. Torres, and J.I. Cubero. 1996. Genetic mapping of new morphological, isozyme and RAPD markers in Vicia faba L. using trisomics. Theor. Appl. Genet. 93:1130-1138.

Schlueter, J., J. Lin, S. Schlueter, I. Vasylenko-Sanders, S. Deshpandem, J. Yi, M. O'Bleness, B. Roe, R. Nelson, B.E. Scheffler, S. Jackson, and R.C. Shoemaker. 2007. Gene duplication and paleopolyploidy in soybean and the implications for whole genome sequencing. BMC Genomics 8:330.

Schlueter, J.A., J.L. Goicoechea, K. Collura, N. Gill, J.Y. Lin, Y. Yu, D. Kudrna, A. Zuccolo, C. E. Vallejos, M. Muñoz-Torres, M.W. Blair, J. Tohme, J. Tomkins, P. McClean, R.A. Wing, and S.A. Jackson. 2008. BAC-end sequence analysis and a draft physical map of the common bean (Phaseolus vulgaris L.) genome. Tropical Plant Biol. 1:40-48.

Schneider, K.A., M.E. Brothers, and J.D. Kelly. 1997. Marker-assisted selection to improve drought resistance in common bean. Crop Sci. 37:51-60.

Schưltze, M., and A. Kondorosi. 1998. Regulation of symbiotic root nodule development. Annu. Rev. Genet. 32:33-57.

Schulze, J., and J.J. Drevon. 2005. P-deficiency increases the $\mathrm{O}_{2}$ uptake per $\mathrm{N}_{2}$ reduced in alfalfa. J. Expt. Bot. 56:1779-1784.

Serraj, R.. 2004. Symbiotic nitrogen fixation: challenges and future prospects for application in tropical agroecosystems. Oxford, IBH, New Delhi, India.

Sharma, H.C.. 2001. Cytoplasmic male-sterility and source of pollen influence the expression of resistance to sorghum midge, Stenodiplosis sorghicola. Euphytica 122:391-395.

Sharma, H.C., G. Pampapathy, S.K. Lanka, and T.J. Ridsdill-Smith. 2005. Antibiosị mechanism of resistance to legume pod borer, Helicoverpa armigera in wild relatives of chickpea. Euphytica 142:107-117.

Sharma, K.K., and M. Lavanya. 2002. Recent developments in transgenics for abiotic stréss in legumes of the semi-arid tropics. pp. 61-73. In: M. Ivanaga (ed.), Genetic engineering of crop plants for abiotic stress. JIRCAS Working Report 23, JRCAS, Tsukuba, Japan.

Shi, A., P. Chen, D.X. Li, C. Zheng, A. Hou, and B. Zhang. 2008. Genetic confirmation of 2 independent genes for resistance to soybean mosaic virus in J05 soybean using SSR markers. J. Hered. 99:598-603.

Shim, J.H., J. Chung, and M.S. Go. 2001. Construction of molecular genetic linkage map using RAPD markers in cowpea. Korean J. Crop Sci. 46:341-343.

Shultz, J.L., S. Kazi, R. Bashir, J.A. Afzal, and D.A. Lightfoot. 2007. The development of $B A C-e n d$ sequence-based microsatellite markers and placement in the physical and genetic maps of soybean. Theor. Appl. Genet. 114:1081-1090.

Sillero, J.C., S. Fondevilla, J. Davidson, M.C. Vaz Patto, T.D. Warkentin, J. Thomas, and D. Rubiales. 2006. Screening techniques and sources of resistance to rusts and mildews in grain legumes. Euphytica 147:255-272. 
Silva, C., and G. Danielle. 2008. Molecular mapping of two loci that confer resistance to Asian rust in soybean. Theor. Appl. Genet. 117:57-63.

Simon, C.J., and F.J. Muehlbauer. 1997. Construction of a chickpea linkage map and its comparison with maps of pea and lentil. J. Hered. 88:115-119.

Singh R.J. 2007. Landmark research in oilseed crops. pp. 1-12. In: R. J. Singh (ed.), Genetic resources, chromosome engineering and crop improvement series: Oilseed crops, Vol 4. CRC Press, Boca Raton, Florida.

Singla, R., and N. Garg. 2005. Influence of salinity on growth and yield attributes in chickpea cultivars. Turkish J. Agric. Forest 29:231-235.

Somta, P., A. Kaga, N. Tomooka, T. Isemura, D.A. Vaughan, and P. Srinives. 2008. Mapping of quantitative trait loci for a new source of resistance to bruchids in the wild species Vigna nepalensis Tateishi and Maxted (Vigna subgenus Ceratotropis). Theor. Appl. Genet. 117:621-628.

Song, Q.J., L.F. Marek, R.C. Shoemaker, K.G. Lark, V.C. Concibido, X. Delannay, J.E. Specht, and P.B. Cregan. 2004. A new integrated genetic linkage map of the soybean. Theor. Appl. Genet. 109:122-128.

Souframanien, J., J.G. Manjaya, T.G. Krishna, and S.E. Pawar. 2003. Random amplified polymorphic DNA analyses of cytoplasmic male sterile and male fertile pigeonpea (Cajanus cajan (L.) Millsp.). Euphytica 129:293-299.

Souza, A.A., R.L. Boscariol, D.H. Moon, L.E. Camargo, and S.M. Tsai. 2000. Effects of Phaseolus vulgaris QTL in controlling host-bacteria interactions under two levels of nitrogen fertilization. Genet. Mol. Bio. 23:155-162.

Specht, J.E., K. Chase, M. Macrander, G.L. Graef, J. Chung, J.P. Markwell, M. Germann, J.H. Orf, and K.G. Lark. 2001. Soybean response to water: A QTL analysis of drought tolerance. Crop Sci. 41:493-509.

Stacey; G., M. Libault, L. Brechenmacher, J. Wan, and G.D. May. 2006. Genetics and functional genomics of legume nodulation. Curr. Opin. Plant. Biol. 9:110-121.

Sun, D., W. Li, Z. Zhang, Q. Chen, H. Ning, L. Qiu, and G. Sun. 2006. Quantitative trait loci analysis for the developmental behavior of Soybean [Glycine max (L.) Merr.]. Theor. Appl. Genet. 112:665-673.

Tadesse, N., K. Ali, D. Gorfu, A. Yusuf, A. Abraham, M. Ayalew, A. Lencho, K.M. Makkouk, and S.G. Kumari. 1999. Survey of chickpea and lentil virus diseases in Ethiopia. Phytopath. Mediter. 38:149-158.

Tamulonis, J.P., B.M. Luzzi, R.S. Hussey, W.A. Parrott, and H.R. Boerma. 1997. DNA markers associated with resistance to Javanese root-knot nematode in soybean. Crop Sci. $37: 783-788$.

Tanksley, S.D., N.D. Young, A.H. Paterson, and M.W. Bonierbalé. 1989. New tools for an old science. Biotech. 7:257-264.

Tar'an, B., T. Warkentin, D.J. Somers, D. Miranda, A. Vandenberg, S. Blade, and D. Bing. 2004. Identification of quantitative trait loci for grain yield, seed protein concentration. and maturity in field pea (Pisum sativum L.). Euphytica 136:297-306.

Tar'an, B., T. Warkentin, D.J. Somers, D. Miranda, A. Vandenberg, S. Blade, S. Woods, D. Bing, A. Xue, D. Dekoeyer, and G. Penner. 2003. Quantitative trait loci for lodging resistance, plant height, and partial resistance to Mycosphaerella blight in field pea (Pisum sativum L.). Theor. Appl. Genet. 107:1482-1491.

Tekeoglu, M., P.N. Rajesh, and F.J. Muehlbauer. 2002. Integration of sequence tagged microsatellite sites to the chickpea genetic map. Theor. Appl. Genet. 105:847-854.

Thibaud-Nissen, F., R.T. Shealy, A. Khanna, and L.O. Vodkin. 2003. Clustering of microarray data reveals transcript patterns associated with somatic embryogenesis in soybean. Plant Physiol. 132:118-136. 
Thoquet, P., M. Ghérardi, Journet, Etienne-Pascal A. Kereszt, J.-M. Ané, J.-M. Prosperi, and T. Huguet. 2002. The molecular genetic linkage map of the model legume Medicago truncatula: an essential tool for comparative legume genomics and the isolation of agronomically important genes. BMC Plant Biol. 2:1.

Timko, M.P., P.J. Rushton, T.W. Laudeman, M.T. Bokowiec, E. Chipumuro, F. Cheung, C.D. Town, and X. Chen. 2008. Sequencing and analysis of the gene-rich space of cowpea. BMC Genomics 9:103.

Timmerman-Vaughan, G.M., T.J. Frew, A.C. Russell; T. Khan, R. Butler, M. Gilpin, S. Murray, and K. Falloon. 2002. QTL mapping of partial resistance to field epidemics of Ascochyta blight of pea. Crop Sci. 42:2100-2111.

Timmerman-Vaughman, G.M., T.J. Frew, R. Butler, S. Murray, M. Gilpin, K. Falloon, P. Johnston, M.B. Lakeman, A. Russell, and T. Khan. 2004. Validation of quantitative trait loci for Ascochyta blight resistance in pea (Pisum sativum L.), using populations from two crosses. Theor. Appl. Genet. 109:1620-1631.

Timmerman-Vaughan, G.M., T.J. Frew, N.F. Weeden, A.I. Miller, and D.S. Goulden. 1994. Linkage analysis of er-1, a recessive Pisum sátivum gene for resistance to powdery mildew fungus (Erysiphe pisi D.C.). Theor. Appl. Genet. 88:1050-1055.

Tivoli, B., A. Baranger, C.M. Avila, S. Banniza, M. Barbetti, W. Chen, J. Davidson, K. Lindeck, M. Kharrat, D. Rubiales, M. Sadiki, J.C. Sillero, M. Sweetingham, and F.J. Muehlbauer. 2006. Screening techniques and sources of resistance to foliar diseases caused by major necrotrophic fungi in grain legumes. Euphytica 147:223-253.

Torres, A.M., N.F. Weeden, and A. Martín. 1993. Linkage among isozyme, RFLP and RAPD markers in Vicia faba. Theor. Appl. Genet. 85:937-945.

Town, C.D.. 2006. Annotating the genome of Medicago truncatula. Curr. Opin. Plant Biol. 9:122-127.

Tsai, S.M., R.O. Nodari, D.H. Moon, L.E.A. Camargo, R. Vencovsky, and P. Gepts. 1998. QTL mapping for nodule number and common bacterial blight in Phaseolus vulgaris L. Plant and Soil. 204:135-145.

Tullu, A., L. Buchwaldt, T. Warkentin, B. Taran, and A. Vandenberg. 2003. Genetics of resistance to anthracnose, and identification of AFLP and RAPD markers linked to the resistance gene in PI 320937 germplasm of lentil (Lens culinaris Medik.). Theor. Appl. Genet. 106:428-434.

Tullu, A., B. Tar'an, T. Warkentin; and A. Vandenberg. 2008. Construction of an intraspecific linkage map and QTL analysis for earliness and plant height in lentil. Crop Sci. 48:2254-2264.

Ubi, B.E., H. Mignouna, and G. Thottappilly. 2000. Construction of a genetic linkage map and QTL analysis using a recombinant inbred population derived from an inter subspecific cross of cowpea (Vigna unguiculata (L.) Walp.). Breed. Sci. 50:161-172.

Udupa, S.M., and M. Baum. 2003. Genetic dissection of pathotypespecific resistance to ascochyta blight disease in chickpea (Cicer arietinum L.) using microsatellite markers. Theor. Appl. Genet. 106:1196-1202.

Vadez, V., S. Rao, J. Kholova, L. Krishnamurthy, J. Kashiwagi, P. Ratnakumar, K.K. Sharma, P. Bhatnagar-Mathur, and P.S. Basu. 2008. Root research for drought tolerance in legumes: quo vadis? J. Food Legumes 21:77-85.

Vallejos, C.E., N.S. Sakiyama, and C.D. Chase. 1992. A molecular marker-based linkage map of Phaseolus vulgaris L. Genetics 131:733-740.

Vance, C.P., P.H. Graham, and D.L. Allan. 2000. Biological nitrogen fixation phosphorus: a critical future need. p. 506-514. In: F.O. Pedrosa, M. Hungria, M.G. Yates, W.E. Newton (eds.), Nitrogen fixation: from molecules to crop productivity. Kluwer Academic Publishers, Dordrecht, The Netherlands. 
Vandemark, G.J., D. Fourie, and P.N. Miklas. 2008. Genotyping with real-time PCR reveals recessive epistasis between independent QTL conferring resistance to common bacterial blight in dry bean. Theor. Appl. Genet. 117:513-522.

van de Ven, W.T.G., R. Waugh, N. Duncan, G. Ramsay, N. Dow, and W. Powell. 1991. Development of a genetic linkage map in Vicia faba using molecular and biochemical techniques. Aspects Appl. Biol. 27:49-54.

Varshney, R.K.. 2009. Gene-based marker systems in plants: high throughput approaches for discovery and genotyping. In: S.M. Jain and D.S. Brar (eds.), Molecular techniques in crop improvement. Vol. 2, Springer, Dordrecht, The Netherlands. (in press).

Varshney, R.K., A. Graner, and M.E. Sorrells. 2005. Genomics-assisted breeding for crop improvement. Trends Plant Sci. 10:621-630.

Varshney, R.K., D.A. Hoisington, and A.K. Tyagi. 2006. Advances in cereal genomics and applications in crop breeding. Trends Biotech. 24:490-499.

Varshney, R.K., D.A. Hoisington, H.D. Upadhyaya, P.M. Gaur, S.N. Nigam, K. Saxena, V. Vadez, N.K. Sethy, S. Bhatia, R. Aruna, M.V.C. Gowda, and N.K. Singh. 2007. Genomic Assisted Crop Improvement. Vol. 2: Genomics applications in crops. pp. 207-242. In: R.K. Varshney and R. Tuberosa (eds.), Molecular genetics and breeding of grain legume crops for the semi-arid tropics. Springer, Dordrecht, The Netherlands.

Varshney, R.K., D.J. Bertioli, M.C. Moretzsohn, V. Vadez, L. Krishnamurthy, R. Aruna, S.N. Nigam, B.J. Moss, K. Seetha, K. Ravi, G. He, S.J. Knapp, and D.A. Hoisington. 2009a. The first SSR-based genetic linkage map for cultivated groundnut (Arachis hypogaea L.). Theor. Appl. Genet. 118:729-739.

Varshney, R.K., T.J. Close, N.K. Singh, D.A. Hoisington, and D.R. Cook. 2009b. Orphan legume crops enter genomics era!. Curr. Opin. Plant Biol. 12:202-210.

Vaz-Patto, M.C., A.M. Torres, A. Koblizkova, J. Macas, and J.I. Cubero. 1999. Development of a genetic composite map of Vicia faba using $\mathrm{F}_{2}$ populations derived from trisomic plants. Theor. Appl. Genet: 98:736-743.

Venancio, S.A., L.G. George, E.S. James, R.S. James, and M.E. Kent. 2001. Identification of QTLs for resistance to Sclerotinia sclerotiorum in soybean. Crop Sci. 41:180-188.

Venter, J.C., M.D. Adams, E.W. Myers, P.W. Li, R.J. Mural, G.G. Sutton, H.O. Smith, M. Yandell; C.A. Evans, R.A. Holt, J.D. Gocayne, and P. Amanatides, et al. 2001. The sequence of the human genome. Science 291:1304-135.

Warkentin, T.D., K.Y. Rashid, and A.G. Xue. 1996. Fungicidal control of powdery mildew in field pea. Can. J. Plant Sci. 76:933-935.

Watanabe, S., T. Teuku, N. Yamanaka, M. Hayashi, and K. Harada. 200A. Analysis of QTLs for reproductive development and seed quality traits in soybean using recombinant inbred lines. Breed: Sci. 54: (4), 399-407.

Winter, P., A.M. Benko-Iseppon, B. Hüttel, M. Ratnaparkhe, A. Tullu, G. Sonnante, T. Pfaff, M. Tekeoglu, D. Santra, V.J. Sant, P.N. Rajesh, G. Kahl, and F.J. Muehlbauer. 2000. A linkage map of chickpea (Cicer arietinum L.) genome based on recombinant inbred lines from a C. arietinum $\times$ C. reticulatum cross: Localizaton of resistance genes for fusarium wilt races 4 and 5. Theor. Appl. Genet. 101:1155-1163.

Winter, P., T. Pfaff,'S.M. Udupa, B. Huttel, P.C. Sharma, S. Sahi, R. Arreguin-Espinoza, F. Weigand, F.J.' Muehlbauer, and G. Kahl. 1999. Characterization and mapping of sequence-tagged microsatellite sites in the chickpea (Cicer arietinum L.) genome. Mol. Gen. Genet. 262:90-101.

Winter, S.M.J., J.B. Shelp, T.R. Anderson, T.W. Welacky, and I. Rajcan. 2006. QTL associated with horizontal resistance to soybean cyst nematode in Glycine soja PI464925B. Theor. Appl. Genet. 114:461-472. 
Wojciechowsiki, M.F., M. Lavin, and M.J. Sanderson. 2004. A phylogeny of legumes (Leguminosae) based on analyses of the plastid matK gene resolves many well-supported subclades within the family. Am. J. Bot. 91:1846-1862.

Wrather, J.A., W.C. Stienstra, and S.R. Koenning. 2001. Soybean disease loss estimates for the United States from 1996 to 1998. Can. J. Plant Path. 23:122-131.

Wrather, J.A., T.R. Anderson, D.M. Arsyad, J. Gai, L.D. Ploper, A. Porta-Puglia, H.H. Ram, and J.T. Yoriniri. 1997. Soybean disease loss estimates for the top soybean producing countries in 1994. Plant Dis. 81:107-110.

Xia, Z., Y. Tsubokura, M. Hoshi, M. Hanawa, C. Yano, K. Okamura, T.A. Ahmed, T. Anai, S. Watanabe, M. Hayashi, T. Kawai, K.G. Hossain, and H. Masaki, K. Asai, N. Yamanaka, N. Kubo, K. Kadowaki, Y. Nagamura, M. Yano, T. Sasaki, K. Harada. 2007. An integrated high-density linkage map of soybean with RFLP, SSR, STS, and AFLP markers using a single F2 population. DNA Res. 14:257-269.

Yamanaka, N., S.M. Ninomiya, Y. Hoshi, M. Tsubokura, Y. Yano, T. Nagamura, T. Sasaki, and K. Harada. 2001. An informative linkage map of soybean reveals QTLs for flowering time, leaflet morphology and regions of segregation distortion. DNA Res. 8:61-72.

Yan, X., H. Liao, S. Beebe, M.W. Blair, and J. Lynch. 2004. QTL mapping of root hair and acid exudation traits and their relationship to phosphorus uptake in common bean. Plant Soil 265:17-29.

Yang, K., J.K. Moon, N. Jeong, K. Back, H.M. Kim, and S.C. Jeong. 2008. Genome-structure in soybean revealed by a genomewide genetic map constructed from a single population. Genomics 92:52-59.

Young, N.D., S.B. Cannon, S. Sato, D. Kim, D.R. Cook, C.D. Town, B.A. Roe, and S. Tabata. 2005. Sequencing the gene spaces of Medicago truncatula and Lotus japonicus. Plant Physiol. 137:1174-1181.

Yu, K., S. Park, B. Zhang, M. Haffner, and V. Poysa. 2004. An SSR marker in the nitrate reductase gene of common bean is tightly linked to a major gene conferring resistance to common bacterial blight. Euphytica 138:89-95.

Zhang, B., P. Chen, C.Y. Chen, D. Wang, A. Shi, and A. Hou. 2008. Quantitative trait loci for seed hardness in soybean. Crop Sci. 48:1341-1349.

Zhang, W.K., Y.J. Wang, G.Z. Luo, J.S. Zhang, C.Y. He, X.L. Wu, J.Y. Gai, and S.Y. Chen. 2004. QTL mapping of ten agronomic traits on the soybean [Glycine max L.Merr.] genetic map and their association with EST markers. Theor. Appl. Genet. 108:1131-1139.

Zhu, H., H.K. Choi, D.R. Cook, and R.C. Shoemaker. 2005. Bridging model and crop legumes through comparative genomics. Plant Physiol. 137:1189-1196. 